\title{
Working
}

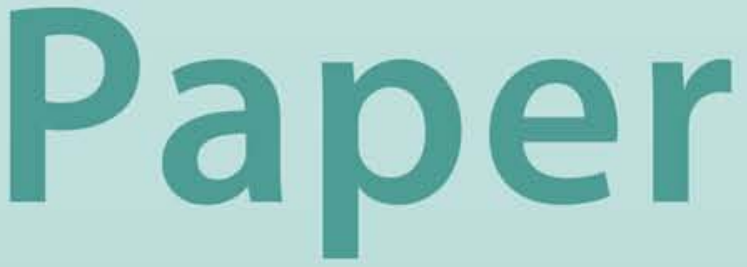




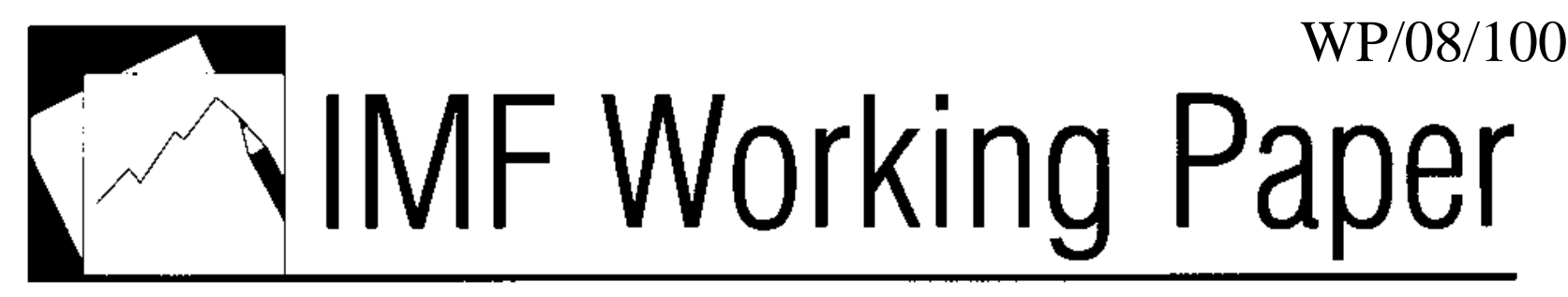

External Shocks and Business Cycle Fluctuations in Mexico:

How Important are U.S. Factors?

Sebastián Sosa 


\title{
IMF Working Paper
}

Western Hemisphere Department

\section{External Shocks and Business Cycle Fluctuations in Mexico: How Important are U.S. Factors?}

\section{Prepared by Sebastián Sosa ${ }^{1}$}

Authorized for distribution by Steve Phillips

April 2008

\begin{abstract}
This Working Paper should not be reported as representing the views of the IMF. The views expressed in this Working Paper are those of the author(s) and do not necessarily represent those of the IMF or IMF policy. Working Papers describe research in progress by the author(s) and are published to elicit comments and to further debate.

This paper examines the relative importance of external shocks as sources of business cycle fluctuations in Mexico, and identifies the dynamic responses of domestic output to foreign disturbances. Using a VAR model with block exogeneity restrictions, it finds that U.S. shocks explain a large share of Mexico's macroeconomic fluctuations after NAFTA. This partly reflects greater trade integration-but also Mexico's “Great Moderation,” as the country escaped its former pattern of macro-financial crises. In this period, Mexico’s output fluctuations have been closely synchronized with the U.S. cycle, with a large and rapid impact of U.S. shocks on Mexican growth.
\end{abstract}

JEL Classification Numbers: E32, F23, F37, F41, F42, F43

Keywords: Mexico, United States, business cycles, external shocks, spillovers, VAR

Author’s E-Mail Address: ssosa@imf.org

\footnotetext{
${ }^{1}$ The author is grateful to Steve Phillips and Roberto García-Saltos for helpful discussions, and to David Robinson, Rodolphe Blavy, Marco Espinosa, Anamaría Pieschacon, and Daniel Chiquiar for their valuable comments on an earlier draft of this paper.
} 
I. Introduction

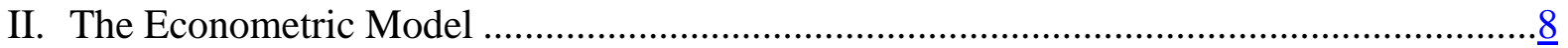

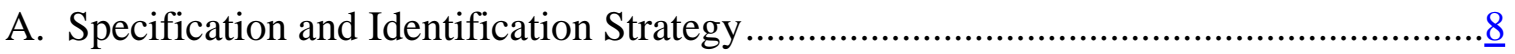

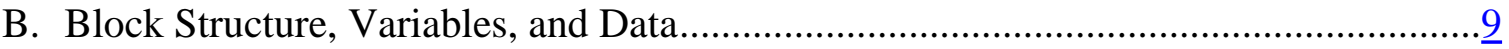

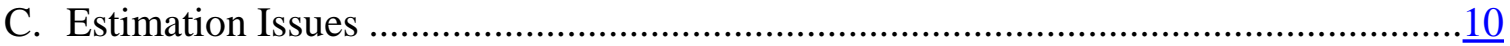

III. The Role of U.S. Demand and Other External Shocks in Mexican Output Fluctuations.. $\underline{10}$

IV. Capturing U.S. Demand Linkages to Mexico: Which U.S. Variables Help Explain Fluctuations in Mexican Economic Activity?

A. Bivariate VARs: Variance Decomposition Analysis ........................................... $\frac{17}{17}$

B. Synchronization Between the U.S. and Mexican Economies ....................................17

V. U.S. Shocks and Business Cycle Fluctuations in Mexico: Potential Spillovers

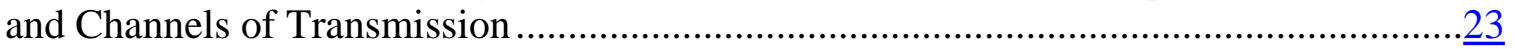

A. Explaining Services Sector GDP, with Unrestricted VAR Models ............................

B. Channels Other Than External Trade? ..............................................................

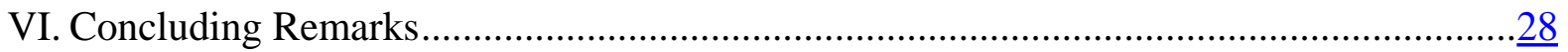

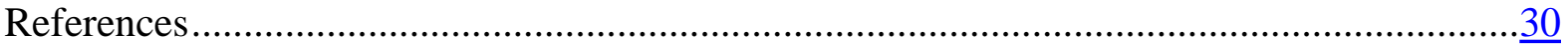

Tables

1. Variance Decomposition of Mexican Real Output: Post-NAFTA Period.........................11

2. Size of the Shocks and Output Response in Mexico: Post-NAFTA.................................12

3. Variance Decomposition of Mexican Real Output: Post-NAFTA Period (Using U.S. GDP as a Proxy for U.S. Demand) .......................................................13

4. Variance Decomposition of Mexican Real Output: Post-NAFTA Period

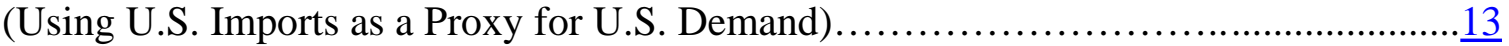

5. Variance Decomposition of Mexican Real Output: Post-NAFTA Period (Using U.S. Real Interest Rate as a Proxy for International Financial Conditions) ...........14

6. Variance Decomposition of Mexican Real Output: Post-NAFTA Period (Using VIX Volatility Index as a Proxy for International Financial Conditions)...............15

7. Variance Decomposition of Mexican Real Output: Post-NAFTA Period (Using Junk Bond Yields as a Proxy for International Financial Conditions) ..................15

8. Variance Decomposition of Mexican Real Output: 1980Q1-2007Q2 ...........................16

9. Size of the Shocks and Output Response in Mexico: 1980Q1-2007Q2 .........................16

10. Mexican GDP and U.S. Variables: Bivariate VARs................................................. 18

11. Mexican Exports and U.S. Variables: Bivariate VARs ...............................................19

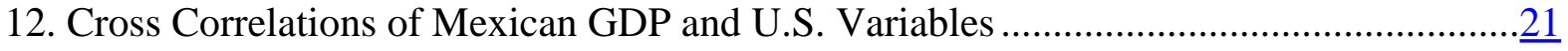

13. Cross Correlations of Mexican Exports and U.S. Variables............................................

14. Cross Correlations of Mexican GDP (Services) and U.S. Variables ................................ 25 
15. Variance Decomposition of Mexico's Real Output in Services ...........................................26

16. Variance Decomposition of Mexico's Real Output in Services

(Using U.S. GDP as a Proxy for U.S. Demand)

17. Variance Decomposition of Mexico's Real Output in Services

(Using U.S. Imports as a Proxy for U.S. Demand)

Figures

1. Response of Real Output to a U.S. Industrial Production Shock.........................................12

2. Response of Real Output to a U.S. GDP Shock ............................................................13

3. Response of Real Output to a U.S. Imports Shock ...........................................................14

4. Response of Real Output to a U.S. Demand Shock (Post-NAFTA and 1980-2007).........16

5. Synchronization Between Mexican GDP and U.S. Variables ..........................................20

6. Synchronization Between Mexican Exports and U.S. Variables.......................................22

7. Synchronization Between Mexican GDP (Services) and U.S. Variables.............................24

8. Response of Real Output in Services to a U.S. Industrial Production Shock ......................26

9. Response of Real Output in Services to a U.S. GDP Shock...............................................

10. Response of Real Output in Services to a U.S. Imports Shock....................... 27 


\section{INTRODUCTION}

In the last two decades, Mexico has undergone a process of trade and financial liberalization and integration, including by entering NAFTA in 1994. While increased integration with the global economy is likely to allow faster trend growth in Mexico, integration may also make the economy more sensitive to certain kinds of external shocks, making external spillovers more relevant in explaining output fluctuations. At the same time, with the implementation of sound and consistent macroeconomic and financial policies in the period since the 1994-95 crisis, Mexico has been able to leave behind its past pattern of crises, avoiding the severe fluctuations and losses of output associated with such episodes. In this way, Mexico has achieved its own "Great Moderation” of the business cycle.

In this light, the importance of shocks related to external trade is likely to have grown over time, at least in relative terms. The share of primary commodities in Mexico's exports has declined over the past 30 years - potentially reducing the relative importance of terms of trade shocks. However, the importance of U.S. cycles in driving output fluctuations in Mexico may have increased with the dramatic expansion of trade between the two countries since the inception of NAFTA. Total trade-exports plus imports-between the two countries increased from about US\$90 billion in 1993 to approximately US\$365 billion in 2007. The U.S. is by far Mexico’s largest trading partner: more than 80 percent of Mexico’s exports are destined to the U.S., and about half of its imports are from the U.S.

Several interesting questions emerge. How significant are external shocks as sources of Mexican business cycle fluctuations? Do shocks stemming from the U.S. indeed play a key — or even a predominant_role in driving domestic output fluctuations? What is the dynamic response of Mexican GDP to a shock affecting the country that absorbs most of Mexico's exports? What are the main transmission mechanisms through which these shocks are propagated to Mexico? The purpose of the paper is to address these questions.

In light of widespread concerns about the health of the U.S. economy, a careful examination of the macroeconomic linkages between the U.S. and Mexican economies is key to assessing the impact of the recent slowdown of the U.S. economic activity on Mexico, and the likely effects of a potential U.S. "hard landing" scenario (involving an abrupt narrowing of the U.S. trade deficit). An identification and assessment of the sources and propagation mechanisms of foreign disturbances is useful not only to characterize Mexican business cycle but also to potentially inform the design and conduct of macroeconomic policy. Moreover, empirical evidence on the sources and transmission channels of external shocks could bring additional perspectives to the issue of regional trade integration and its economic effects.

The empirical strategy used to study the sources of macroeconomic fluctuations and to identify the responses of the Mexican economy to external disturbances is a VAR model with block exogeneity restrictions. The model contains two blocks—one block of foreign variables and one of domestic variables. This specification assumes that foreign variables are 
completely exogenous to the Mexican domestic economy. ${ }^{2}$ The paper focuses on the linkages between the U.S. and Mexican economies, trying to shed some light on the potential spillovers and channels of transmission underlying them.

The main results and conclusions are as follows:

- $\quad$ Shocks to U.S. demand for Mexico's exports—as proxied by U.S. industrial production-represent a major factor driving macroeconomic fluctuations in Mexico (in fact constituting the largest source of foreign disturbances) in the post-NAFTA period, accounting for about 35 percent of output fluctuations. These results are robust to the use of alternative measures of U.S. demand for Mexico's exports (such as U.S. GDP, and U.S. total imports).

- $\quad$ A positive innovation to U.S. industrial production increases Mexican output on impact with effects continuing over six quarters, and the largest response occurs only one quarter after the shock. The size of the effect of U.S. activity on Mexican GDP is rather large. As a "rule of thumb," an innovation of 1 percentage point in U.S. industrial production growth would typically be accompanied by a change of 0.9 percentage point in Mexican GDP growth one quarter after the shock. ${ }^{3}$

- $\quad$ The key role played by U.S. demand shocks is seen mainly in the post-NAFTA period. If a longer period starting at 1980 is considered, the relative importance of the role played by U.S. influences is substantially smaller. These differing results can be explained mainly by the greater importance of idiosyncratic shocks in the pre-NAFTA period, in particular the economic and financial crisis episodes in Mexico, and probably also reflect the lesser degree of trade integration with the U.S before NAFTA.

- U.S. output variables — industrial production and GDP — appear to be more important for Mexican output than U.S. domestic demand indicators. This fact probably reflects the extent to which Mexico's exports consist of intermediate goods used as inputs in U.S. production, rather than final goods.

\footnotetext{
${ }^{2}$ The block exogeneity approach in VAR models has been previously used in the literature on external shocks and macroeconomic fluctuations in both developed and developing countries. For instance, Cushman and Zha (1997), Dungey and Pagan (2000), Hoffmaister and Roldos (2001), Buckle and others (2002), Franken, Le Fort and Parrado (2005), and Sosa and Cashin (2008) applied this approach to Canada, Australia, Brazil, Korea, New Zealand, Chile, and the ECCU. Raddatz (2006) quantified the impact of different external shocks and determined their contributions to output volatility in low-income countries. Finally, Osterholm, and Zettelmeyer (2007) developed a Bayesian VAR with block exogeneity to investigate the sensitivity of GDP growth - for an aggregated group of the largest Latin American economies - to external developments.

${ }^{3}$ Throughout this paper, the "rule of thumb" elasticities derived from impulse response functions are computed considering the effects at the peak quarter, and not the cumulative-and typically larger-effects over longer periods, such as 8 or 12 quarters.
} 
- For perspective, Mexico's exports to the U.S. are now roughly one-fourth of Mexican GDP (and value-added from such exports must be significantly smaller, taking into account the high import content of many exports). Evidently, the effect of U.S. output fluctuations goes far beyond its immediate and direct influence on Mexico's exports. Indeed, changes in U.S. economic activity are also important in driving-directly or indirectly - output fluctuations in the services sector, which accounts for more than 65 percent of Mexican GDP. Given the presumably small direct exposure-through trade channels - of the services sector to the U.S. economy, these results suggest the existence of important spillovers or multiplier effects stemming from the export sector to the rest of the Mexican economy, as well as the existence of other (non-trade) channels through which shocks originated in the U.S. are transmitted to Mexico.

Business cycles in Mexico have been studied extensively in the literature using different approaches, usually with a focus on the U.S. economy (or NAFTA) as the key external influence. Oliveira Santos (2002) uses a regime-switching model to characterize business cycles in Mexico. Herrera (2003) tests and measures the existence of common cycles between the economies of Mexico and the U.S., finding that both economies share a common trend and a common cycle. Cuevas, Messmacher, and Werner (2003) analyze changes in the degree of macroeconomic synchronization between Mexico and its NAFTA partners, and find that synchronization increased after the inception of NAFTA. ${ }^{4}$ They also show that this has occurred in a large number of economic sectors and regions, reinforcing traditional links between these countries. Torres and Vela (2003) examine the relationship between business cycles in Mexico and the U.S., and find that, as the manufacturing sectors of the two economies have become more integrated through trade linkages, business cycles across the border have become more synchronized. ${ }^{5}$ More recently, Swiston and Bayoumi (2008) examine the linkages across North America by estimating the size of spillovers from the major regions of the world to Canada and Mexico; their results show that since 1996 U.S. shocks have played an influential role in driving the Mexican business cycle.

The related literature also includes Chiquiar and Ramos-Francia (2004), who study the changes in the degree and the nature of synchronization between Mexico and the U.S. manufacturing output levels. ${ }^{6}$ They provide evidence that production-side links between Mexico and U.S. manufacturing sectors became stronger after NAFTA was enacted and, as a consequence, business cycles in these countries became more synchronized. Jean Louis and Simons (2005) use Markov-switching regimes in a multivariate framework to investigate the business cycle linkages in North America, and find that Mexico and Canada

\footnotetext{
${ }^{4}$ Their empirical approach is based on correlation and regression analyses, as well as on factor analysis.

${ }^{5}$ Their study is mostly based on co-movement and regression analyses.

${ }^{6}$ In particular, they apply spectral analysis and cointegration tests to assess the correlation of the business cycle and low frequency components of the manufacturing output series of the two countries.
} 
individually share a common cycle with the U.S. but not with each other. ${ }^{7}$ Kose, Meredith, and Towe (2004) provide an overall assessment of the impact of NAFTA on growth and business cycles in Mexico. Finally, Bergin, Feenstra, and Hanson (2006) develop two theoretical models of outsourcing that can explain how domestic demand shocks in the U.S. are transmitted in an amplified manner to Mexican outsourcing industries.

This paper builds on this literature in several ways:

- $\quad$ First, while most of the work in this area has examined the synchronization between Mexico and its NAFTA partners, we are not aware of any studies that seek to measure the relative importance of different types of external shocks - and their importance vis-à-vis idiosyncratic shocks - in explaining Mexican output fluctuations in a unified framework, and to determine the dynamic responses of the Mexican economy to each of them. Whereas most previous studies have focused on individual external factors (e.g., U.S. growth, oil price movements, etc.), the use of a VAR model with block exogeneity allows us to assess not only the direct effect of changes in each of the foreign variables included in the external block of the model, but also the indirect effect through reactions in other foreign and domestic variables.

- $\quad$ Second, we also put emphasis on the magnitude of the responses of Mexican GDP to individual shocks. For example, "rule of thumb” elasticities are derived from the impulse response functions, which can help inform conditional forecasts, for example, of how much Mexico would be affected by a change in the outlook for U.S. growth.

- $\quad$ Finally, this paper is able to add several years' more data to the analysis of the post-NAFTA era. By including the most recent period-through end-2007-the analysis can provide some clues on the causes of the recent slowdown of Mexican growth, and on whether the strong relationships found in the earlier literature continue to hold.

The rest of the paper is organized as follows. The next section describes the econometric approach. Section III examines the relative importance of U.S. demand shocks - and other foreign disturbances - in explaining Mexican output fluctuations, and identifies the dynamic response of Mexico's output to these shocks. Section IV investigates which U.S. variables are most relevant to explain business cycles in Mexico. Section V analyses potential spillovers and channels of transmission underlying the linkages between the U.S. and Mexican economies. Finally, Section VI presents some concluding remarks, including identifying some outstanding questions and areas for further research.

\footnotetext{
7 They investigate other issues including the role of the common cycle in explaining each country's economic fluctuations and the responses of each country to a common shock.
} 


\section{THE ECONOMETRIC MODEL}

The empirical approach to determine the relative importance of external shocks as sources of business cycle fluctuations in Mexico, and to identify the dynamic responses of domestic output to U.S. shocks is a standard VAR model with block exogeneity restrictions. A key feature of the model is that foreign variables are assumed to be completely exogenous to the Mexican domestic economy.

\section{A. Specification and Identification Strategy}

The structural model can be expressed—omitting the constant terms for simplicity—as:

$$
A(L) y_{t}=\gamma_{t}
$$

where $y_{t}$ is an $n$ vector of variables, $A(L)$ denotes a lag polynomial matrix, and $\gamma_{t}$ is an $n$ vector of structural disturbances or shocks. $A_{0}$, which represents the contemporaneous relationships between the variables of the model, is a non-singular matrix normalized to have ones on the diagonal.

The reduced form corresponding to this structural model can be written as:

$$
B(L) y_{t}=u_{t}
$$

where $B(L)$ is a lag polynomial matrix such that $B(L)=\left(A_{0}\right)^{-1} A(L)$ and $B_{0}=I$, and $u_{t}$ is an $n$ vector of mean zero reduced form disturbances with covariance matrix $\Gamma$, such that $u_{t}=\left(A_{0}\right)^{-1} \gamma_{t}$.

In order to identify the structural parameters, a set of restrictions must be specified. Following Sims (1980), the reduced form errors are orthogonalized by Choleski decomposition. The selected Choleski ordering is characterized by the idea that the external variables of the model precede the Mexican domestic economic variables. This ordering implies that foreign variables do not instantly respond to Mexican domestic variables, but the domestic variables may be affected by contemporaneous changes in external conditions.

It is worth noting, however, that the restrictions implied by such ordering refer only to the contemporaneous relationships between the variables of the model. To assume complete exogeneity of the foreign variables, lagged values of the domestic variables should not affect them either. This is achieved by imposing block exogeneity restrictions. Hence, the model is separated in two blocks of equations: one external block and one domestic economy block. The domestic economic variables are completely absent from equations in the external block, meaning that shocks to domestic variables cannot affect, neither contemporaneously nor with any lags, the external variables.

The block exogeneity approach implies that some of the VAR equations have regressors not included in others. This type of model is known as "near-VAR" in the literature. The block 
exogeneity procedure reduces the number of parameters to be estimated, which helps to limit the erosion of degrees of freedom and to improve the efficiency of the estimation.

\section{B. Block Structure, Variables, and Data}

Critical external factors for Mexico are likely to include terms of trade, global financial conditions, and external demand. Hence, the external block of the model includes oil prices, ${ }^{8}$ world real interest rates, ${ }^{9}$ and U.S. demand for Mexican exports as proxies for these factors. The domestic block, in turn, includes real output - the variable of main interest, as well as the real exchange rate- which may play a key role in macroeconomic adjustment to external shocks — and capital inflows — a variable which has been mentioned in the literature ${ }^{10}$ as highly correlated with the business cycle in emerging market countries, and an important driver of their output fluctuations.

Oil prices are measured as the average of three crude oil spot prices (Dated Brent, WTI, and Dubai Fateh), in U.S. dollars per barrel. The world real interest rate is computed using the six-month LIBOR and the CPI inflation rate of industrial countries. Alternative measures to capture international financial conditions include the U.S. real interest rate (three-month T-bill rate deflated by the U.S. CPI), the S\&P 500 VIX volatility index, and U.S. junk bond yields (as a proxy for global risk appetite). U.S. demand for Mexican exports is proxied by U.S. industrial production (sa, 2002=100), U.S. real GDP (saar, in billions of chained 2000 dollars), and U.S. real imports of goods and services (from National Accounts, saar, in billions of chained 2000 dollars). Capital inflows are measured as the net flow of money from abroad (net transfers received plus capital inflows minus accumulation of international reserves minus net payments of interest, dividends, profit remittances, etc.). Finally, the real exchange rate and real output are measured using the real effective exchange rate index and Mexican GDP (saar, million of 1993 new pesos). ${ }^{11}$

\footnotetext{
${ }^{8}$ Mexico is among the world's top ten oil exporters, in absolute terms, although the value of its oil exports as a percent of GDP is much less than in some other countries. Oil revenues account for almost 40 percent of budget revenue.

${ }^{9}$ Changes in international real interest rates constitute an important factor driving portfolio capital inflows to Latin America, thus influencing business cycles across the region (Calvo, Leiderman, and Reinhart, 1993, and Calvo, Fernandez Arias, Reinhart, and Talvi, 2001). This link between international interest rates and capital flows to Latin America (and to emerging markets in general) may be a consequence of a number of reasons. Low interest rates in mature markets may lead investors in those markets to seek higher returns in other markets, increasing the demand for emerging market assets. Not only does external financing become more abundant for emerging markets, but also the cost of borrowing declines as a consequence of the lower interest rates in the U.S. In fact, Fernandez Arias (1996) shows that country-risk premia in emerging markets is indeed affected by international interest rates, amplifying the interest rate cycles in mature markets.

${ }^{10}$ Calvo, Fernandez Arias, Reinhart, and Talvi (2001), and Kaminski, Reinhart, and Vegh (2004).

${ }^{11}$ The data sources are the IMF's International Financial Statistics (IFS), Bank of Mexico, and Haver Analytics.
} 
The model is estimated using quarterly data from 1995 (or 1980 when analyzing a longer period) through 2007Q4. All the variables-except the world real interest rate and capital flows - are expressed in log levels, and the model is estimated in first differences. ${ }^{12}$

\section{Estimation Issues}

Standard VAR models may be estimated by Ordinary Least Squares (OLS). However, as noted before, the model developed in this paper is a near-VAR (given the block exogeneity restrictions, not all the equations include the same regressors). When some of the equations in a VAR present regressors not included in others, Seemingly Unrelated Regressions (SUR) appear to provide more efficient estimates of the coefficients than OLS. The efficiency gains are larger the higher the correlation of the residuals across equations. Therefore, in this paper the system is estimated using SUR rather than OLS.

The specification of the estimated equations follows from the block exogeneity restrictions mentioned earlier. The model is estimated with four lags - the lag length being selected according to the Akaike Information Criterion (AIC).

\section{THE Role OF U.S. DEMAND AND OTHER EXTERNAL SHOCKS IN MEXiCAN OUTPUT FLUCTUATIONS}

The main objectives of the paper are achieved through two standard tools of VAR analysis: impulse response functions and variance decomposition. Variance decomposition provides a quantification of the relative importance of each of the shocks as sources of output fluctuations. Impulse responses constitute a practical way to identify the dynamic responses of the domestic economy to external shocks, illustrating how growth in Mexico has tended to react to U.S. and other external shocks - taking into account not only the direct effects of disturbances, but also the indirect effect through reactions of other endogenous variables.

Shocks to U.S. demand for Mexican exports—proxied by U.S. industrial production, toward which many Mexican exports are destined—represent a major factor driving output fluctuations in Mexico in the post-NAFTA period, accounting for about 35 percent of GDP fluctuations (Table 1). Shocks to international financial conditions are also significant, explaining about 20 percent of output fluctuations, while oil price shocks account for only 6 percent. ${ }^{13}$ The relative importance of U.S. demand shocks appears to be larger in Mexico than in the rest of Latin America, according to two recent studies conducted at the IMF:

\footnotetext{
${ }^{12}$ Standard unit root tests (augmented Dickey-Fuller) show that all variables are stationary in first differences. In addition, most cointegration tests suggest that the variables in the model are not cointegrated (i.e., the null hypothesis of no cointegration cannot be rejected). Hence, it seems adequate to estimate the model in first differences. It is worth noting that Chiquiar and Ramos-Francia (2004) found a cointegration relationship between Mexican and U.S. manufacturing output in the post-NAFTA period.

${ }^{13}$ For a horizon of eight quarters, which is when the percentages stabilize.
} 
Osterholm and Zettelmeyer (2007), and IMF (2007) show that U.S. demand shocks (proxied by U.S. GDP) accounted for 16 percent of the variance of Latin American GDP growth in the period from 1994 through $2006 .{ }^{14}$ However, the overall influence of external shocks in Mexico seems to be similar to that in the rest of the region. While external shocks account for about 60 percent of output fluctuations in Mexico, these other studies find that external factors explain 57 percent in the case of Latin America. ${ }^{15}$

Table 1. Variance Decomposition of Mexican Real Output: Post-NAFTA Period (in percent)

\begin{tabular}{cccccccccc}
\hline Horizon & $\begin{array}{c}\text { Standard } \\
\text { Error }\end{array}$ & Oil price & $\begin{array}{c}\text { World real } \\
\text { interest rate }\end{array}$ & $\begin{array}{c}\text { US industrial } \\
\text { production }\end{array}$ & $\begin{array}{c}\text { Capital inflows } \\
\text { REER }\end{array}$ & $\begin{array}{c}\text { Real GDP 1/ } \\
\text { External } \\
\text { shocks }\end{array}$ & $\begin{array}{c}\text { Idiosyncratic } \\
\text { shocks }\end{array}$ \\
\hline 1 & 0.0046 & 4.68 & 0.58 & 3.41 & 4.77 & 4.55 & 82.00 & 8.68 & 91.32 \\
4 & 0.0079 & 5.91 & 15.91 & 34.22 & 4.76 & 6.30 & 32.91 & 56.04 & 43.97 \\
8 & 0.0086 & 6.08 & 19.47 & 34.07 & 4.21 & 7.33 & 28.85 & 59.62 & 40.38 \\
12 & 0.0087 & 6.44 & 21.17 & 33.33 & 4.11 & 7.15 & 27.81 & 60.93 \\
\hline
\end{tabular}

1/ This column indicates the proportion of fluctuations in real GDP explained by its "own" shocks.

Shocks to U.S. activity appear to have quite large, and rapid, effects on Mexican GDP. Figure 1 shows the dynamic response of Mexico’s GDP growth to a one standard deviation positive shock to U.S. industrial production growth: output increases on impact, with a lasting effect of six quarters, and the largest response occurs only one quarter after the shock. ${ }^{16}$ A "rule of thumb" elasticity can be derived from the impulse response, which indicates that a 1 percentage point increase in U.S. industrial production growth leads to an increase in Mexican GDP growth of 0.9 percentage points after one quarter. The output response to shocks to the other variables in the model is shown in Table $2 .^{17}$

\footnotetext{
${ }^{14}$ Latin American growth is measured using a weighted index for Argentina, Brazil, Chile, Colombia, Mexico, and Peru, which together represent about 90 percent of Latin American output.

${ }^{15}$ Izquierdo, Romero, and Talvi (2007) also find that external factors account for a significant share of the variance of Latin American GDP growth, for the period 1990-2006. Other studies have quantified the fraction of output fluctuations explained by external factors in different countries and regions. External shocks explain 11 percent of real output fluctuations in low-income countries, 27 percent in Brazil and 29 percent in Korea, 43 percent in Chile, 54 percent in the ECCU, and 72 percent in Canada, according to Raddatz (2006), Hoffmaister and Roldos (2001), Franken, Le Fort and Parrado (2005), Sosa and Cashin (2008), and Cushman and Zha (1997), respectively. This comparison should be considered only as suggestive or illustrative, since the econometric strategies and identification procedures used, the variables included, and time periods analyzed differ across studies.

${ }^{16}$ A one-standard deviation shock to U.S. industrial production growth is equal to 0.51 percentage points.

${ }^{17}$ It may be argued that other domestic factors—especially public expenditure — might also play a role in driving output fluctuations in Mexico. Therefore, in an alternative version of the model, the VAR was estimated including government consumption in the domestic block. The results do not change substantially. In particular, the percentage of Mexican output fluctuations explained by U.S. real shocks, as well as the dynamic response of Mexican GDP to a shock to U.S. industrial production do not vary significantly. Moreover, the relative importance of government consumption in explaining business cycle fluctuations is very small in Mexico, and the dynamic response of Mexican output to a shock to public expenditure is not statistically significant.
} 


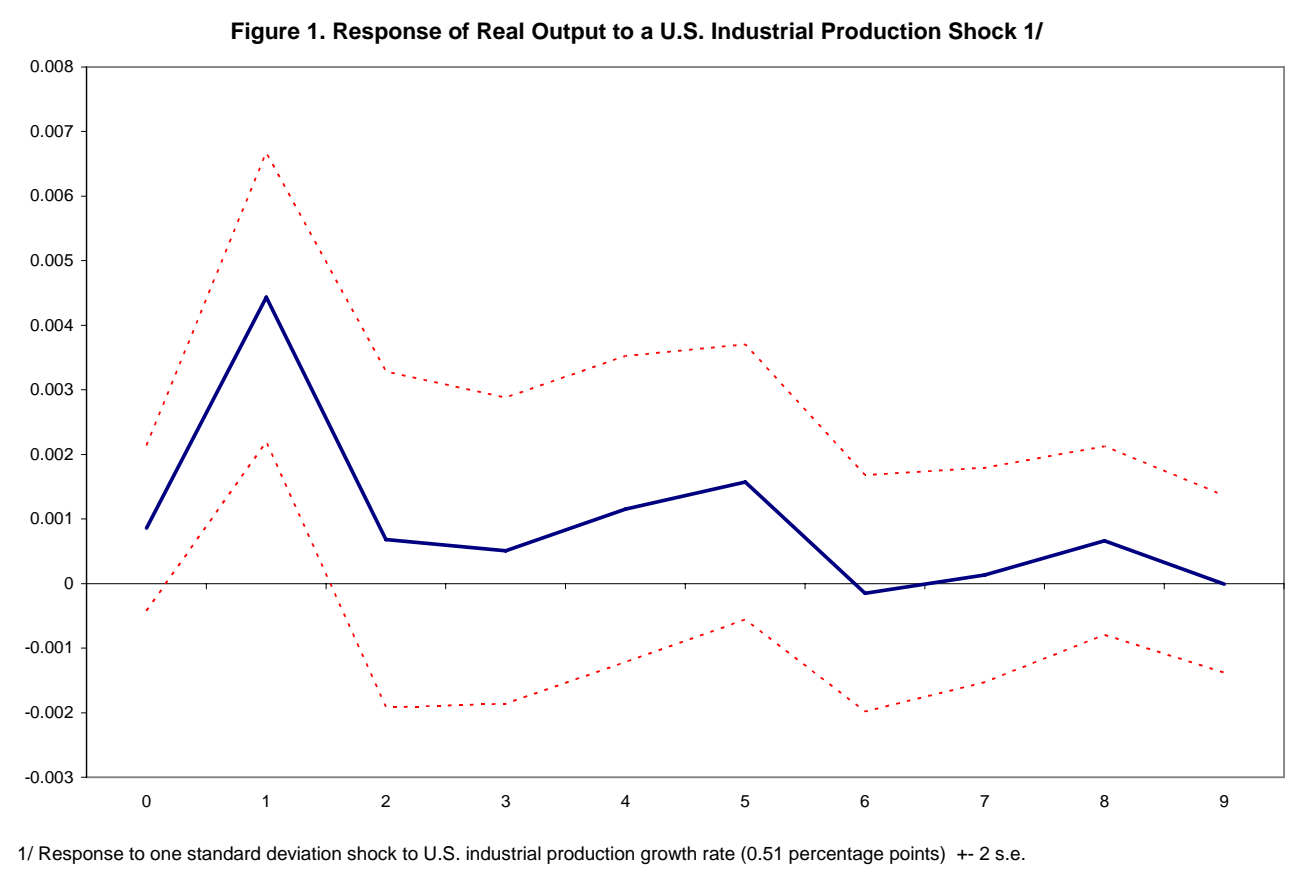

Table 2. Size of the Shocks and Output Response in Mexico: Post-NAFTA (one standard deviation shock)

\begin{tabular}{lccc}
\hline \multicolumn{1}{c}{ Type of shock } & Size of shock & $\begin{array}{c}\text { Peak quarter } \\
\text { (after the shock) }\end{array}$ & $\begin{array}{c}\text { GDP response } \\
\text { (at peak) }\end{array}$ \\
\hline Oil price & 0.104 & 1 & 0.0011 \\
World real interest rate & 0.420 & 8 & -0.0012 \\
U.S. industrial production & 0.005 & 1 & 0.0044 \\
Capital inflows & 209.4 & 0 & 0.0010 \\
REER & 0.035 & 1 & -0.0015 \\
\hline
\end{tabular}

To check the robustness of the results, the VAR model is alternatively estimated using U.S. GDP and U.S. total imports as proxies for U.S. demand for Mexican exports, instead of U.S. industrial production. The results do not change substantially, with U.S. GDP and imports accounting for 33 percent and 31 percent of business cycle fluctuations respectively (Tables 3 and 4). ${ }^{18}$ Positive (one standard deviation) shocks to U.S. GDP and U.S. total imports are expansionary again, with the largest effects occurring one quarter after the shock-although with a considerable effect in the contemporaneous quarter as well. (Figures 2 and 3). ${ }^{19}$ The derived "rule of thumb" elasticity suggests that a one percentage

\footnotetext{
${ }^{18}$ Swiston and Bayoumi (2008) find similar results, with U.S. GDP growth accounting for about 31 percent of the variance of Mexico's GDP growth in the period 1996-2007.

${ }^{19}$ A one-standard deviation shock amounts to 0.4 percentage points in the case of U.S. GDP growth and to 1.3 percentage points in the case of U.S. imports.
} 
point increase in U.S. GDP growth leads to an increase in Mexican GDP growth of 0.7 percentage points after one quarter. A one percentage point increase in U.S. imports growth, in turn, increases Mexico’s growth by 0.3 percentage points.

Table 3. Variance Decomposition of Mexican Real Output: Post-NAFTA Period (in percent, using U.S. GDP as a proxy for U.S. demand)

\begin{tabular}{cccccccccc}
\hline Horizon & $\begin{array}{c}\text { Standard } \\
\text { Error }\end{array}$ & Oil price & $\begin{array}{c}\text { World real } \\
\text { interest rate }\end{array}$ & U.S. GDP & $\begin{array}{c}\text { Capital inflows } \\
\text { REER }\end{array}$ & $\begin{array}{c}\text { Real GDP 1/ } \\
\text { shocks }\end{array}$ & $\begin{array}{c}\text { Idiosyncratic } \\
\text { shocks }\end{array}$ \\
\hline 1 & 0.0049 & 8.16 & 1.75 & 20.08 & 15.99 & 1.46 & 52.56 & 29.99 \\
4 & 0.0078 & 5.59 & 24.23 & 24.97 & 14.97 & 4.61 & 25.64 & 54.79 & 45.21 \\
8 & 0.0085 & 5.91 & 22.74 & 32.53 & 12.78 & 3.95 & 22.08 & 61.19 \\
12 & 0.0087 & 7.25 & 23.24 & 32.03 & 12.44 & 3.84 & 21.21 & 62.51 \\
\hline
\end{tabular}

1/ This column indicates the proportion of fluctuations in real GDP explained by its "own" shocks.

Table 4. Variance Decomposition of Mexican Real Output: Post-NAFTA Period (in percent, using U.S. total imports as a proxy for U.S. demand)

\begin{tabular}{|c|c|c|c|c|c|c|c|c|c|}
\hline Horizon & $\begin{array}{l}\text { Standard } \\
\text { Error }\end{array}$ & Oil price & $\begin{array}{l}\text { World real } \\
\text { interest rate }\end{array}$ & $\begin{array}{l}\text { U.S. total } \\
\text { imports }\end{array}$ & Capital inflows & REER & Real GDP 1/ & $\begin{array}{l}\text { External } \\
\text { shocks }\end{array}$ & $\begin{array}{l}\text { Idiosyncratic } \\
\text { shocks }\end{array}$ \\
\hline 1 & 0.0053 & 0.29 & 9.41 & 25.96 & 8.61 & 0.10 & 55.63 & 35.66 & 64.34 \\
\hline 4 & 0.0086 & 7.72 & 18.59 & 34.04 & 10.20 & 5.73 & 23.73 & 60.34 & 39.66 \\
\hline 8 & 0.0094 & 6.92 & 19.72 & 31.34 & 12.69 & 5.23 & 24.11 & 57.97 & 42.03 \\
\hline 12 & 0.0096 & 8.41 & 19.13 & 31.18 & 12.82 & 5.05 & 23.42 & 58.71 & 41.29 \\
\hline
\end{tabular}

1/ This column indicates the proportion of fluctuations in real GDP explained by its "own" shocks.

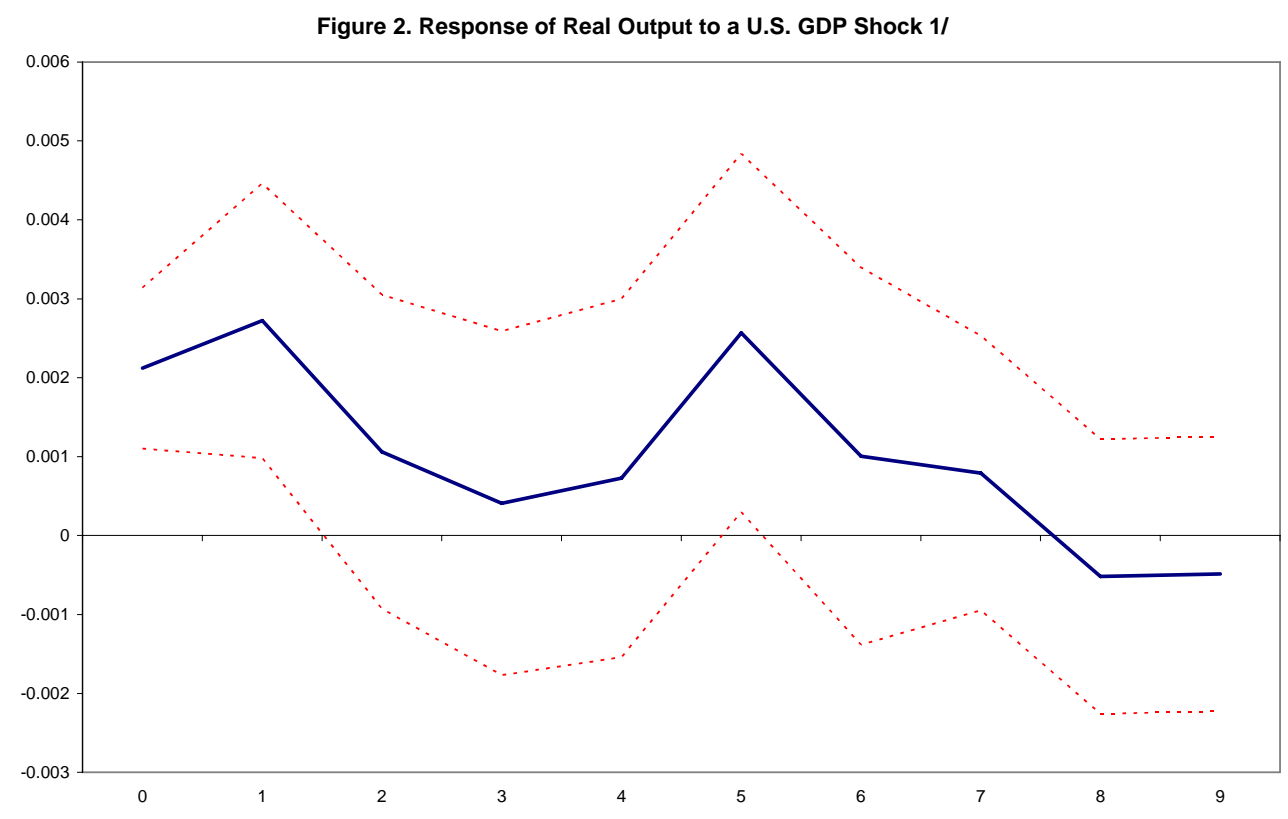

1/ Response to one standard deviation shock to U.S. GDP growth rate ( 0.4 percentage points) +-2 s.e. 


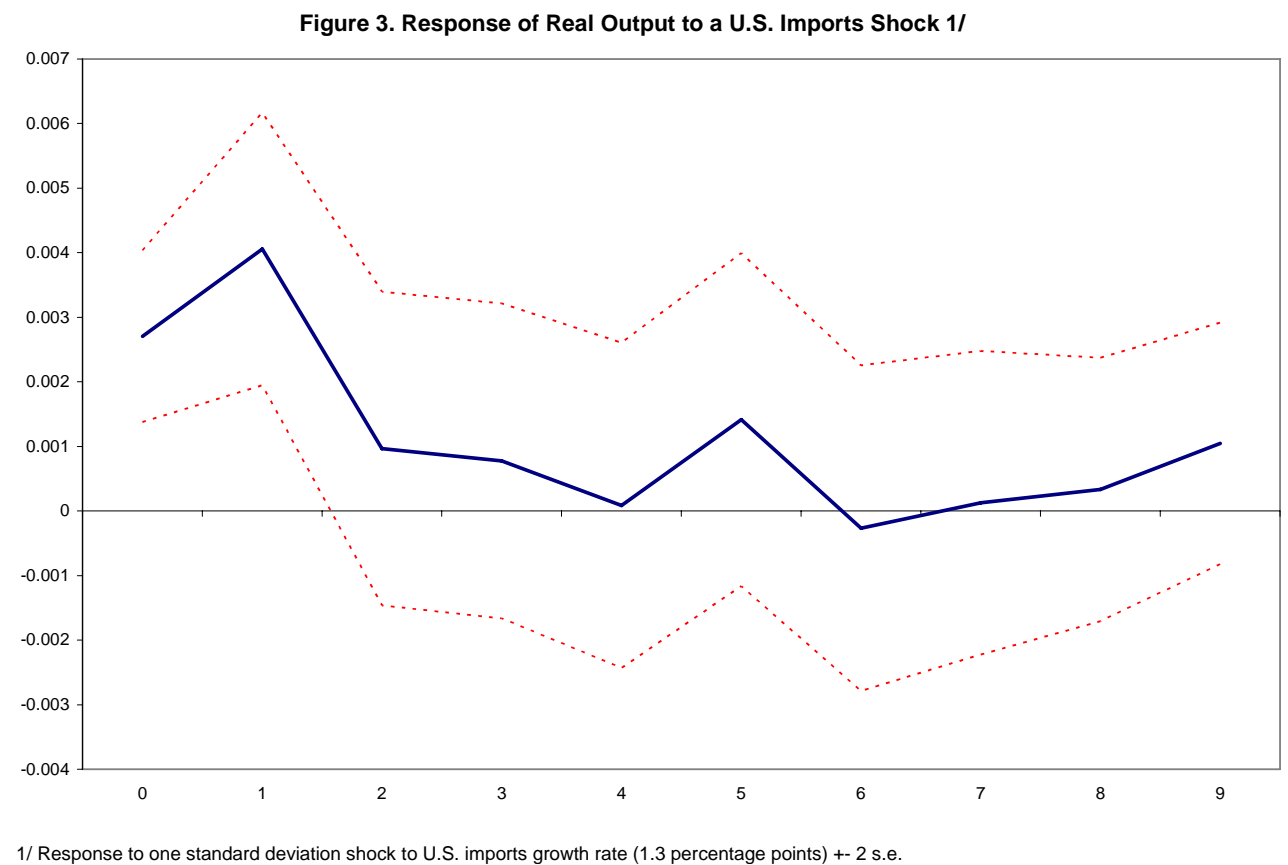

The VAR model is also estimated using other variables to capture international financial conditions: the U.S. real interest rate, the VIX volatility index, and U.S. junk bond yields (as a proxy for global risk appetite). The role played by external factors in explaining Mexican output fluctuations does not change dramatically, with a higher fraction explained by U.S. growth and smaller fractions by each of the alternative financial variables, compared with the specification using world real interest rates (Tables 5, 6, and 7). The dynamic response of Mexican output to a (one standard deviation) U.S. growth shock is fairly similar under these alternative specifications, with the "rule of thumb" elasticities ranging from 0.7 to 0.9 , which implies that a positive innovation in U.S. growth is passed on to Mexico almost one-for-one. $^{20}$

Table 5. Variance Decomposition of Mexican Real Output: Post-NAFTA Period (in percent, using U.S. real interest rate as a proxy for international financial conditions)

\begin{tabular}{cccccccccc}
\hline Horizon & $\begin{array}{c}\text { Standard } \\
\text { Error }\end{array}$ & Oil price & $\begin{array}{c}\text { U.S. real } \\
\text { interest rate }\end{array}$ & U.S. GDP & Capital inflows & REER & Real GDP 1/ & $\begin{array}{c}\text { External } \\
\text { shocks }\end{array}$ & $\begin{array}{c}\text { Idiosyncratic } \\
\text { shocks }\end{array}$ \\
\hline 1 & 0.0052 & 8.51 & 2.02 & 16.51 & 13.97 & 1.87 & 57.12 & 27.04 & 72.96 \\
4 & 0.0074 & 5.87 & 9.12 & 37.45 & 11.29 & 4.24 & 32.02 & 52.44 & 47.56 \\
8 & 0.0078 & 5.86 & 8.33 & 42.30 & 10.41 & 3.94 & 29.15 & 56.49 & 43.51 \\
12 & 0.0079 & 7.33 & 9.34 & 41.00 & 10.22 & 3.92 & 28.18 & 57.68 & 42.32 \\
\hline
\end{tabular}

1/ This column indicates the proportion of fluctuations in real GDP explained by its "own" shocks.

\footnotetext{
${ }^{20}$ Osterholm and Zettelmeyer (2007), and IMF (2007) find that the average reaction of Latin American growth to a shock in U.S. growth is also about one-for-one.
} 
Table 6. Variance Decomposition of Mexican Real Output: Post-NAFTA Period (in percent, using VIX volatility index as a proxy for international financial conditions)

\begin{tabular}{|c|c|c|c|c|c|c|c|c|c|}
\hline Horizon & $\begin{array}{l}\text { Standard } \\
\text { Error }\end{array}$ & Oil price & U.S. GDP & $\begin{array}{l}\text { VIX volatility } \\
\text { index }\end{array}$ & Capital inflows & REER & Real GDP 1/ & $\begin{array}{l}\text { External } \\
\text { shocks }\end{array}$ & $\begin{array}{l}\text { Idiosyncratic } \\
\text { shocks }\end{array}$ \\
\hline 1 & 0.0046 & 13.46 & 20.17 & 1.55 & 14.42 & 1.17 & 49.23 & 35.18 & 64.82 \\
\hline 4 & 0.0076 & 7.61 & 42.16 & 4.08 & 16.34 & 5.95 & 23.85 & 53.85 & 46.15 \\
\hline 8 & 0.0083 & 7.96 & 44.22 & 7.46 & 14.09 & 5.21 & 21.07 & 59.64 & 40.36 \\
\hline 12 & 0.0084 & 9.61 & 42.78 & 7.80 & 14.07 & 5.32 & 20.43 & 60.19 & 39.81 \\
\hline
\end{tabular}

1/ This column indicates the proportion of fluctuations in real GDP explained by its "own" shocks.

Table 7. Variance Decomposition of Mexican Real Output: Post-NAFTA Period (in percent, using junk bond yields as a proxy for international financial conditions)

\begin{tabular}{cccccccccc}
\hline Horizon & $\begin{array}{c}\text { Standard } \\
\text { Error }\end{array}$ & Oil price & U.S. GDP & $\begin{array}{c}\text { Junk bond } \\
\text { yields }\end{array}$ & $\begin{array}{c}\text { Capital inflows } \\
\text { REER }\end{array}$ & $\begin{array}{c}\text { Real GDP 1/ } \\
\text { External } \\
\text { shocks }\end{array}$ & $\begin{array}{c}\text { Idiosyncratic } \\
\text { shocks }\end{array}$ \\
\hline 1 & 0.0048 & 4.59 & 21.32 & 5.82 & 1.45 & 2.30 & 64.51 & 31.73 \\
4 & 0.0071 & 5.13 & 42.60 & 12.67 & 3.03 & 1.90 & 34.66 & 60.41 & 39.59 \\
8 & 0.0080 & 7.28 & 43.21 & 14.01 & 4.43 & 2.03 & 29.05 & 64.50 & 35.50 \\
12 & 0.0085 & 9.57 & 40.25 & 16.80 & 5.62 & 2.08 & 25.69 & 66.61 \\
\hline
\end{tabular}

$1 /$ This column indicates the proportion of fluctuations in real GDP explained by its "own" shocks.

The key role played by U.S. demand shocks is a phenomenon observed mainly in the post-NAFTA period. In fact, if we consider a longer period, starting at 1980 instead of 1995, changes in U.S. industrial production account for less than 5 percent of output fluctuations in Mexico, ${ }^{21}$ and the impact of a (one standard deviation) shock to U.S. demand is also smaller (Table 8 and Figure 4). ${ }^{22}$ These differing results can be explained mainly by the greater importance of idiosyncratic shocks in the pre-NAFTA period, in particular in the economic and financial crisis episodes in Mexico, and probably also reflect the lesser degree of trade integration with the U.S before NAFTA. In fact, over the last decade, Mexico's output fluctuations have been of the "normal business cycle” variety, and closely synchronized with that of the U.S.. ${ }^{23}$

\footnotetext{
${ }^{21}$ This result is also consistent with Swiston and Bayoumi (2007). In fact, they find that shocks to U.S. GDP growth explain 5 percent of Mexican output fluctuations in the period 1970-2007.

${ }^{22}$ A one-standard deviation shock to U.S. industrial production is equal to 0.65 percentage points.

${ }^{23}$ The output response to shocks to the other variables for the longer period is shown in Table 9 . The size of the shocks - in particular idiosyncratic shocks—appears to be larger in the pre-NAFTA period. Moreover, the Mexican economy in general seems to be more resilient to shocks in the post-NAFTA period (except in the case of U.S. demand shocks).
} 
Table 8. Variance Decomposition of Mexican Real Output: 1980Q1-2007Q4 (in percent)

\begin{tabular}{cccccccccc}
\hline Horizon & $\begin{array}{c}\text { Standard } \\
\text { Error }\end{array}$ & Oil price & $\begin{array}{c}\text { World real } \\
\text { interest rate }\end{array}$ & $\begin{array}{c}\text { US industrial } \\
\text { production }\end{array}$ & $\begin{array}{c}\text { Capital inflows } \\
\text { Real GDP 1/ }\end{array}$ & $\begin{array}{c}\text { External } \\
\text { shocks }\end{array}$ & $\begin{array}{c}\text { Idiosyncratic } \\
\text { shocks }\end{array}$ \\
\hline 1 & 0.0096 & 6.30 & 0.30 & 0.64 & 1.94 & 1.71 & 89.12 & 7.23 \\
4 & 0.0130 & 10.93 & 3.53 & 0.67 & 19.11 & 12.52 & 53.24 & 15.13 & 84.87 \\
8 & 0.0137 & 11.80 & 5.39 & 2.72 & 19.58 & 11.97 & 48.55 & 19.90 & 80.10 \\
12 & 0.0137 & 11.99 & 5.44 & 2.87 & 19.51 & 11.98 & 48.21 & 20.30 \\
\hline
\end{tabular}

$1 /$ This column indicates the proportion of fluctuations in real GDP explained by its "own" shocks.

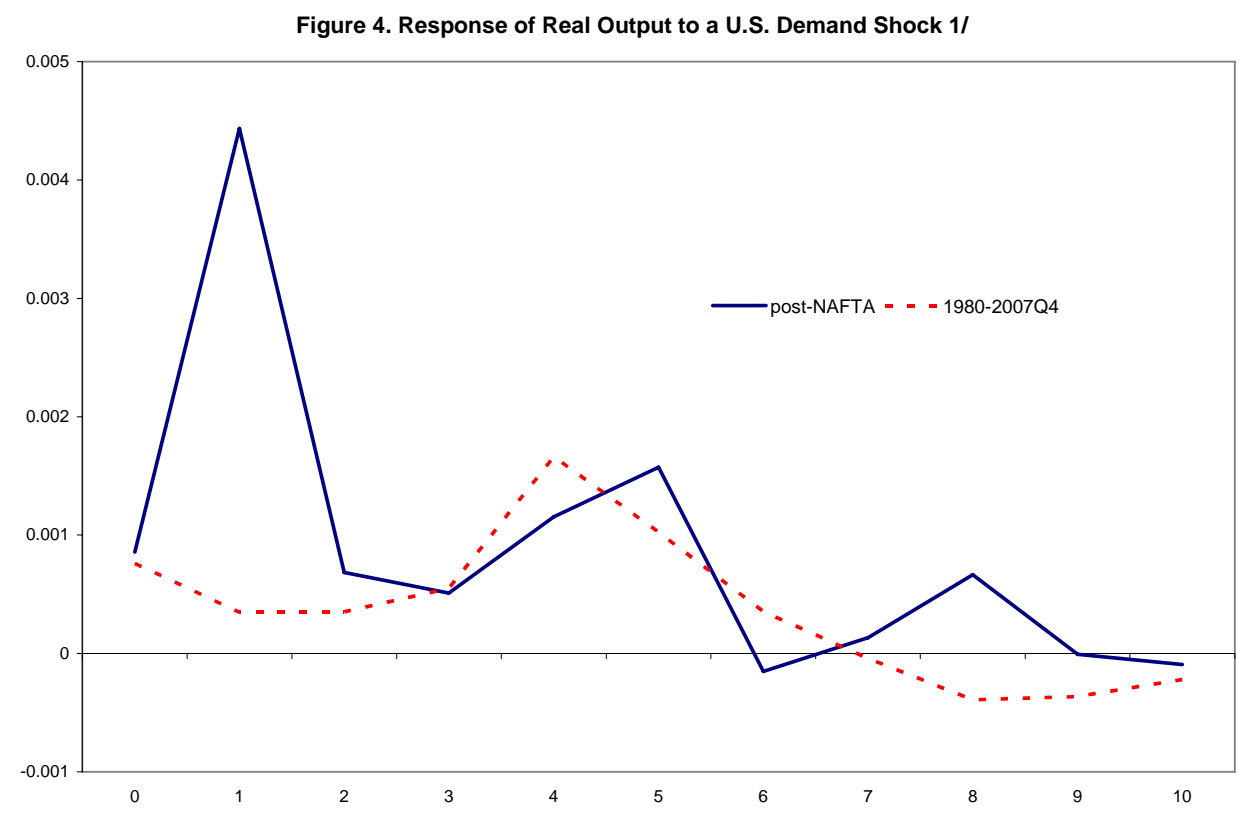

1/ One standard deviation shocks to U.S. industrial production growth rate (post-NAFTA: 0.51 percentage points; 1980-2007Q4=0.65 percentage

Table 9. Size of the Shocks and Output Response in Mexico: 1980Q1-2007Q4 (one standard deviation shock)

\begin{tabular}{lccc}
\hline \multicolumn{1}{c}{ Type of shock } & Size of shock & $\begin{array}{c}\text { Peak quarter } \\
\text { (after the shock) }\end{array}$ & $\begin{array}{c}\text { GDP response } \\
\text { (at peak) }\end{array}$ \\
\hline Oil price & 0.122 & 1 & 0.0027 \\
World real interest rate & 0.666 & 3 & -0.0022 \\
U.S. industrial production & 0.006 & 4 & 0.0017 \\
Capital inflows & 457.7 & 1 & 0.0046 \\
REER & 0.055 & 1 & -0.0043 \\
\hline
\end{tabular}




\section{Capturing U.S. Demand Linkages to MeXico: Which U.S. VARIABLeS HELP EXPLAIN FLUCTUATIONS IN MEXICAN ECONOMIC ACTIVITY?}

Two exercises are performed to address this question, focusing on the post-NAFTA period. First, variance decomposition analysis from a number of simple bivariate VARs is conducted, to determine what fraction of the fluctuations in Mexican activity is explained by changes in the corresponding U.S. variable. ${ }^{24}$ Second, the synchronization between the Mexican and U.S. economic variables is examined. Both exercises are conducted with the aim of explaining not only GDP but also export fluctuations in Mexico in the post-NAFTA period. $^{25}$

\section{A. Bivariate VARs: Variance Decomposition Analysis}

As in the case of the multivariate VARs examined in the previous section, U.S. industrial production, GDP and total imports each can explain a large share of output fluctuations in Mexico, accounting for 45, 43, and 31 percent respectively (Table 10). In regard to components of U.S. industrial production, durable manufacturing appears to play a larger role than non-durable manufacturing. In terms of U.S. domestic demand, private investment explains a larger fraction than private consumption (27 percent and 20 percent respectively). Auto sales in the U.S., in turn, can explain 20 percent of Mexico’s GDP fluctuations.

The analogous exercise was also conducted to explain fluctuations in Mexican exports: it turns out that U.S. industrial production —in particular durable goods manufacturing —as well as U.S. GDP and total imports can also explain a large fraction of fluctuations in Mexican exports (Table 11). Other U.S. variables with important explanatory power are private investment, private consumption, and auto sales.

\section{B. Synchronization Between the U.S. and Mexican Economies}

The important role played by U.S. factors in determining output (and export) fluctuations in Mexico after NAFTA is consistent with the higher synchronization between the U.S. and Mexican business cycles during that period, a phenomenon that has been documented in the previous literature. ${ }^{26}$ Here, we use simple time-series charts and cross-correlograms to illustrate this synchronization, and to confirm that it has continued in the most recent years (using data through end-2007).

\footnotetext{
${ }^{24}$ The bivariate VAR models allow for 4 lags, and are estimated in first differences using quarterly data. Standard Choleski decomposition is used, and the ordering is such that the U.S. variable precedes the Mexican variable.

${ }^{25}$ The exports time series used is Mexico's real exports of goods and services (from National Accounts, saar, in millions of 1993 new pesos).

${ }^{26}$ See, for instance, Torres and Vela (2003), Cuevas, Messmacher and Werner (2003), and Chiquiar and Ramos-Francia (2004).
} 
Table 10. Mexican GDP and U.S. Variables: Bivariate VARs (post-NAFTA period)

\begin{tabular}{|c|c|}
\hline VAR's variables & $\begin{array}{c}\text { Variance decomposition of Mexican output } \\
\% \text { explained by US variable }\end{array}$ \\
\hline \multicolumn{2}{|c|}{ MEX GDP - US ind. prod. } \\
\hline 4 quarters & 43.7 \\
\hline 8 quarters & 45.5 \\
\hline \multicolumn{2}{|c|}{ MEX GDP - US IP durable manufacturing } \\
\hline 4 quarters & 42.6 \\
\hline 8 quarters & 45.4 \\
\hline \multicolumn{2}{|c|}{ MEX GDP - US GDP } \\
\hline 4 quarters & 41.3 \\
\hline 8 quarters & 42.6 \\
\hline \multicolumn{2}{|c|}{ MEX GDP - US Imports } \\
\hline 4 quarters & 30.6 \\
\hline 8 quarters & 30.8 \\
\hline \multicolumn{2}{|c|}{ MEX GDP - US IP non-durable manufacturing } \\
\hline 4 quarters & 29.4 \\
\hline 8 quarters & 29.1 \\
\hline \multicolumn{2}{|c|}{ MEX GDP - US private investment } \\
\hline 4 quarters & 20.4 \\
\hline 8 quarters & 26.6 \\
\hline \multicolumn{2}{|c|}{ MEX GDP - US auto sales } \\
\hline 4 quarters & 19.8 \\
\hline 8 quarters & 20.3 \\
\hline \multicolumn{2}{|c|}{ MEX GDP - US private consumption } \\
\hline 4 quarters & 19.6 \\
\hline 8 quarters & 20.1 \\
\hline \multicolumn{2}{|c|}{ MEX GDP - US imports, auto } \\
\hline 4 quarters & 18.4 \\
\hline 8 quarters & 18.5 \\
\hline \multicolumn{2}{|c|}{ MEX GDP - US IP motor, vehicles and parts } \\
\hline 4 quarters & 13.9 \\
\hline 8 quarters & 15.2 \\
\hline \multicolumn{2}{|c|}{ MEX GDP - US imports, ind. supplies and materials } \\
\hline 4 quarters & 11.2 \\
\hline 8 quarters & 12.6 \\
\hline
\end{tabular}


Table 11. Mexican Exports and U.S. Variables: Bivariate VARs (post-NAFTA period)

\begin{tabular}{|c|c|}
\hline VAR's variables & $\begin{array}{c}\text { Variance decomposition of Mexican exports } \\
\% \text { explained by US variable }\end{array}$ \\
\hline \multicolumn{2}{|c|}{ MEX exports - US IP durable manufacturing } \\
\hline 4 quarters & 49.7 \\
\hline 8 quarters & 49.4 \\
\hline \multicolumn{2}{|c|}{ MEX exports - US GDP } \\
\hline 4 quarters & 48.4 \\
\hline 8 quarters & 47.3 \\
\hline \multicolumn{2}{|c|}{ MEX exports - US ind. prod. } \\
\hline 4 quarters & 41.4 \\
\hline 8 quarters & 42.1 \\
\hline \multicolumn{2}{|c|}{ MEX exports - US Imports } \\
\hline 4 quarters & 39.0 \\
\hline 8 quarters & 39.4 \\
\hline \multicolumn{2}{|c|}{ MEX exports - US private investment } \\
\hline 4 quarters & 34.6 \\
\hline 8 quarters & 34.2 \\
\hline \multicolumn{2}{|c|}{ MEX exports - US private consumption } \\
\hline 4 quarters & 31.3 \\
\hline 8 quarters & 33.1 \\
\hline \multicolumn{2}{|c|}{ MEX exports - US auto sales } \\
\hline 4 quarters & 25.0 \\
\hline 8 quarters & 26.3 \\
\hline \multicolumn{2}{|c|}{ MEX exports - US IP motor, vehicles and parts } \\
\hline 4 quarters & 22.8 \\
\hline 8 quarters & 25.2 \\
\hline \multicolumn{2}{|c|}{ MEX exports - US imports, auto } \\
\hline 4 quarters & 21.3 \\
\hline 8 quarters & 23.0 \\
\hline \multicolumn{2}{|c|}{ MEX exports - US imports, ind. supplies and materials } \\
\hline 4 quarters & 10.3 \\
\hline 8 quarters & 11.2 \\
\hline \multicolumn{2}{|c|}{ MEX exports - US IP non-durable manufacturing } \\
\hline 4 quarters & 6.7 \\
\hline 8 quarters & 8.2 \\
\hline
\end{tabular}

Figure 5 illustrates the striking comovement between Mexican output and a number of U.S. variables during the period 1996Q1-2007Q4. Even in a sample span of only 12 years, there are enough fluctuations in the data to make readily apparent a tight relationship. Of particular interest is the close alignment of turning points. This alignment is observed not only during the sample's dominant event (the 2001-02 recession-recovery) but also during fluctuations over the most recent years. The high positive correlation between these variables can also be observed in the cross-correlogram in Table 12. The correlation coefficient with Mexican GDP is about 0.8 for U.S. GDP, and even higher for U.S. industrial production (and 
the sub-component durable manufacturing), and U.S. imports. For all these variables the highest coefficient corresponds to the contemporaneous correlation.

Figure 5. Synchronization Between Mexican GDP and U.S. Variables (1996Q1-2007Q4, yoy \% changes)
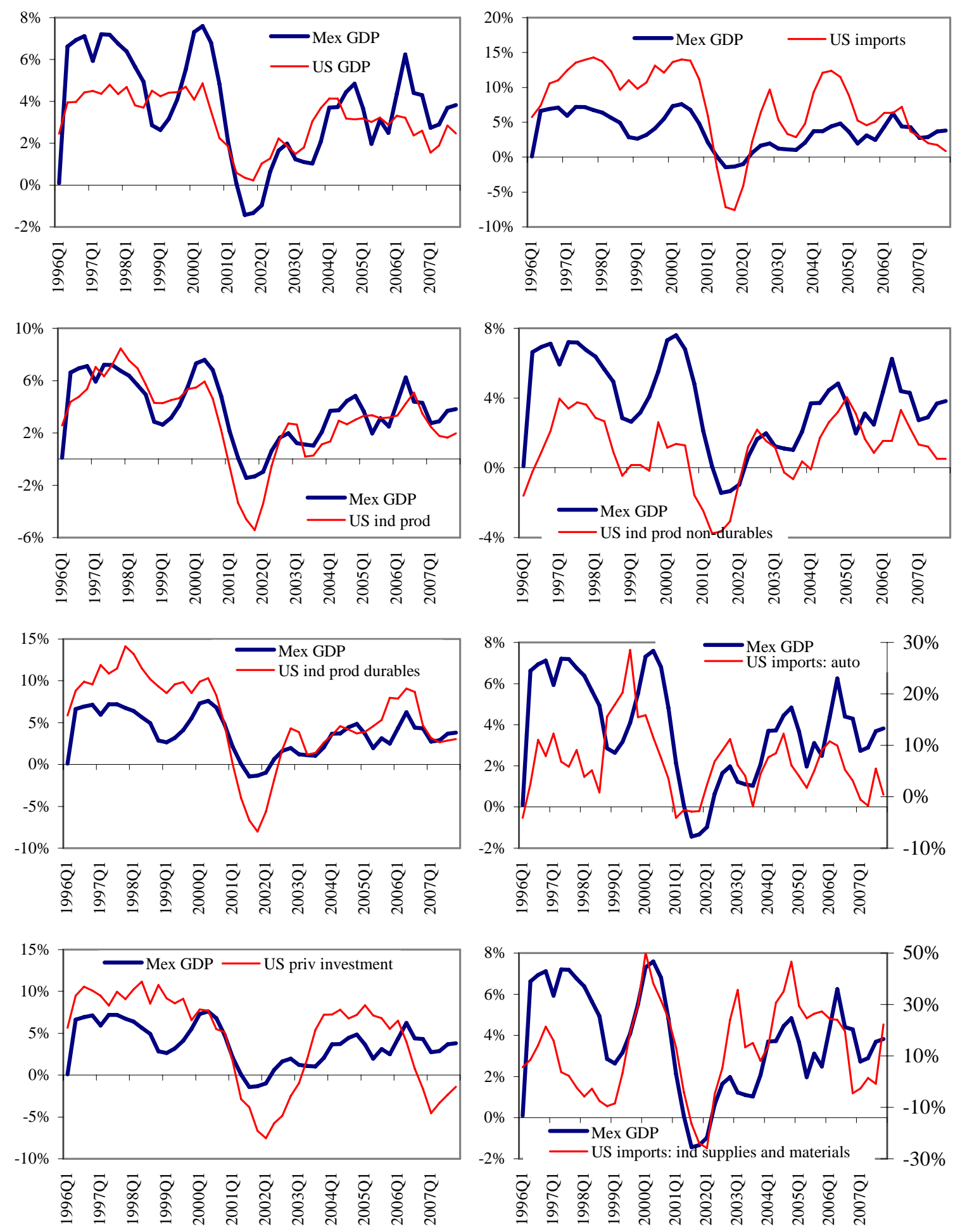
Table 12. Cross Correlations of Mexican GDP and U.S. Variables (yoy percent change, post-Nafta period) $1 /$

\begin{tabular}{|c|c|c|c|c|c|c|c|c|c|}
\hline \multirow[t]{2}{*}{ U.S variable } & \multicolumn{9}{|c|}{ Cross correlations of Mexican real GDP in period $t$ and U.S. variable in period } \\
\hline & $t-4$ & $t-3$ & $t-2$ & $t-1$ & $t$ & $t+1$ & $t+2$ & $t+3$ & $t+4$ \\
\hline Industrial production & 0.35 & 0.49 & 0.65 & 0.80 & 0.85 & 0.78 & 0.58 & 0.34 & 0.14 \\
\hline I.P: durable manuf. & 0.39 & 0.52 & 0.68 & 0.81 & 0.84 & 0.76 & 0.56 & 0.37 & 0.21 \\
\hline Total imports & 0.16 & 0.32 & 0.52 & 0.71 & 0.81 & 0.74 & 0.50 & 0.26 & 0.06 \\
\hline GDP & 0.43 & 0.59 & 0.73 & 0.79 & 0.79 & 0.61 & 0.42 & 0.26 & 0.16 \\
\hline Private investment & 0.44 & 0.51 & 0.60 & 0.67 & 0.67 & 0.60 & 0.48 & 0.38 & 0.30 \\
\hline I.P.: non-durable manuf. & 0.23 & 0.33 & 0.44 & 0.56 & 0.62 & 0.52 & 0.28 & -0.01 & -0.23 \\
\hline Private consumption & 0.18 & 0.33 & 0.42 & 0.49 & 0.51 & 0.45 & 0.41 & 0.38 & 0.37 \\
\hline US imports: ind. supplies & -0.06 & 0.06 & 0.22 & 0.36 & 0.42 & 0.33 & 0.08 & -0.19 & -0.39 \\
\hline US imports: auto & 0.31 & 0.42 & 0.48 & 0.46 & 0.41 & 0.20 & -0.04 & -0.13 & -0.12 \\
\hline I.P.: motor, vehicles and parts & 0.35 & 0.43 & 0.43 & 0.33 & 0.21 & -0.05 & -0.26 & -0.31 & -0.28 \\
\hline Auto and light truck sales & 0.27 & 0.38 & 0.32 & 0.26 & 0.12 & -0.04 & -0.03 & 0.01 & 0.09 \\
\hline
\end{tabular}

1/ Numbers in bold correspond to the peak quarter.

Table 13 and Figure 6 show the high synchronization between Mexican exports and the different U.S. variables. The comovement—as in the case of Mexican GDP_is striking, and turning points also appear to be closely aligned. The cross-correlogram, in turn, shows that the highest correlation coefficients are those corresponding to U.S. imports, industrial production — especially the category durable manufacturing - and GDP, and in all these cases the contemporaneous coefficients appear to be the highest (except in the case of U.S. GDP, which appears to lead Mexican output by one quarter).

Table 13. Cross Correlations of Mexican Exports and U.S. Variables (yoy percent change, post-NAFTA period) $1 /$

\begin{tabular}{|c|c|c|c|c|c|c|c|c|c|}
\hline \multirow[t]{2}{*}{ U.S variable } & \multicolumn{9}{|c|}{ Cross correlations of Mexican real exports in period $t$ and U.S. variable in period } \\
\hline & $t-4$ & $t-3$ & $t-2$ & $t-1$ & $t$ & $t+1$ & $t+2$ & $t+3$ & $t+4$ \\
\hline Total imports & 0.13 & 0.25 & 0.46 & 0.70 & 0.82 & 0.76 & 0.52 & 0.27 & 0.07 \\
\hline I.P: durable manuf. & 0.35 & 0.44 & 0.61 & 0.77 & 0.81 & 0.74 & 0.55 & 0.35 & 0.21 \\
\hline Industrial production & 0.34 & 0.42 & 0.58 & 0.73 & 0.78 & 0.74 & 0.53 & 0.33 & 0.17 \\
\hline GDP & 0.36 & 0.52 & 0.71 & 0.80 & 0.77 & 0.63 & 0.43 & 0.31 & 0.21 \\
\hline Private investment & 0.36 & 0.46 & 0.60 & 0.68 & 0.73 & 0.68 & 0.53 & 0.44 & 0.31 \\
\hline Private consumption & 0.18 & 0.36 & 0.54 & 0.59 & 0.56 & 0.47 & 0.34 & 0.30 & 0.33 \\
\hline US imports: ind. supplies & -0.07 & 0.01 & 0.16 & 0.35 & 0.47 & 0.47 & 0.30 & 0.02 & -0.25 \\
\hline US imports: auto & 0.29 & 0.33 & 0.48 & 0.51 & 0.46 & 0.30 & 0.08 & -0.04 & -0.12 \\
\hline I.P.: non-durable manuf. & 0.29 & 0.30 & 0.37 & 0.44 & 0.41 & 0.39 & 0.20 & 0.03 & -0.08 \\
\hline Auto and light truck sales & 0.22 & 0.38 & 0.44 & 0.29 & 0.21 & 0.08 & -0.01 & 0.03 & 0.13 \\
\hline I.P.: motor, vehicles and parts & 0.40 & 0.39 & 0.47 & 0.38 & 0.15 & -0.06 & -0.30 & -0.36 & -0.27 \\
\hline
\end{tabular}

$1 /$ Numbers in bold correspond to the peak quarter. 
Figure 6. Synchronization Between Mexican Exports and U.S. Variables (1996Q1-2007Q4, yoy \% changes)
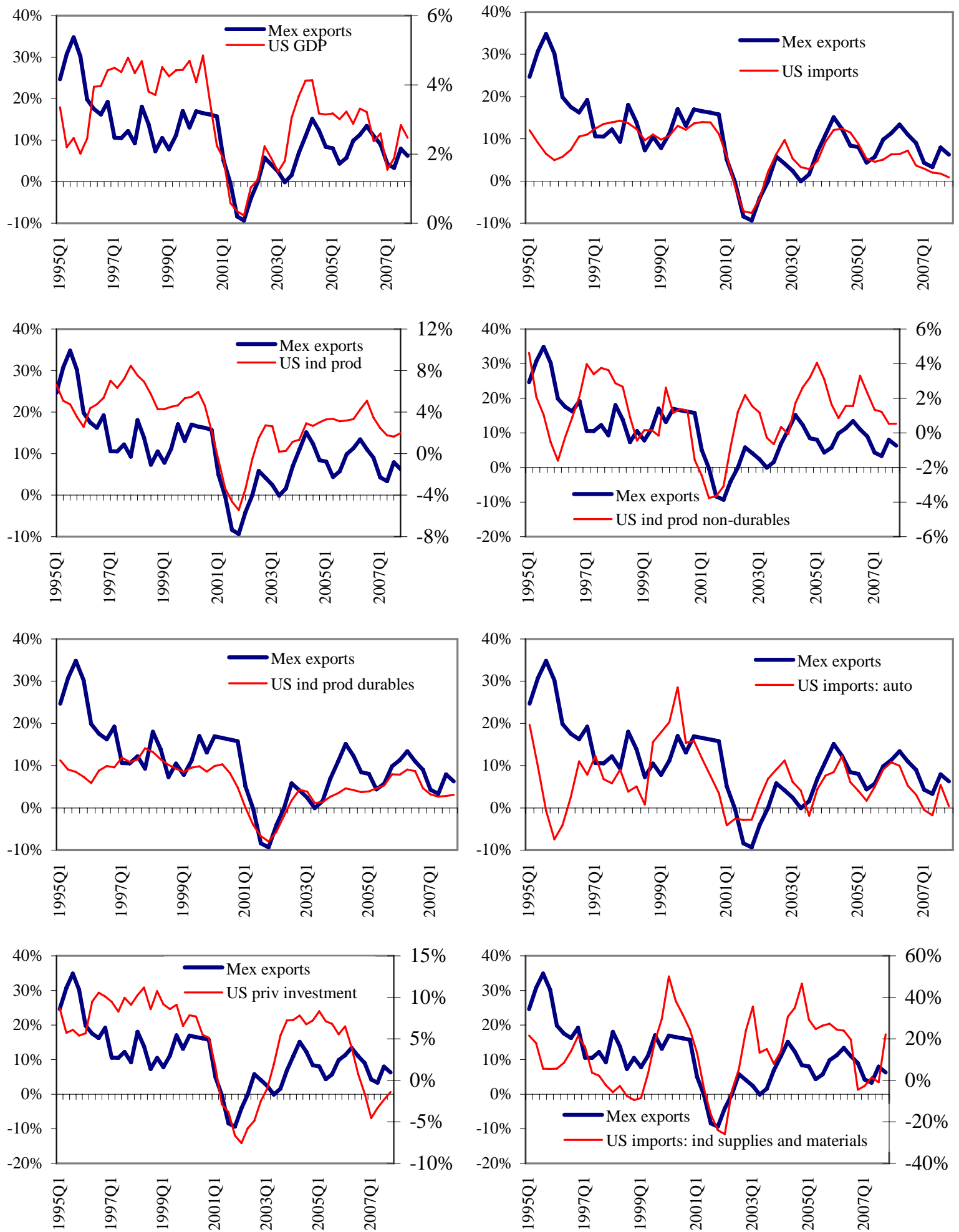
As noted earlier, U.S. output variables - industrial production and GDP-appear to be more important for Mexican output than indicators of U.S. demand. This fact probably reflects the extent to which Mexico’s exports consist of intermediate goods used as inputs in U.S. production, rather than final goods.

\section{U.S. Shocks ANd Business Cycle Fluctuations in Mexico: Potential SPILLOVERS AND CHANNELS OF TRANSMISSION}

The apparently strong influence of fluctuations in U.S. real variables on Mexico's output fluctuations is particularly interesting given the still relatively low share of exports in Mexico's output. Certainly, external trade is important to Mexico: total exports have grown to roughly 30 percent of GDP, of which about 25 percent of GDP goes to the U.S. However, value added from the export sector must be significantly less than these numbers, in light of the very high import content of many exports, particularly those of the maquila sector.

In this context, the structure of production and specialization patterns induced by trade integration may help explain how trade shocks could be amplified. ${ }^{27}$ As emphasized above, U.S. output variables_-industrial production and GDP_-appear to be more relevant for Mexican output than U.S. demand indicators, probably reflecting the extent to which Mexico’s exports consist of intermediate goods used as inputs in U.S. production, rather than final goods. Indeed, the importance of intra-industry trade in transmitting U.S. shocks to Mexico has been highlighted in the literature. Chiquiar and Ramos-Francia (2004) argue that the increased synchronization of Mexico and U.S. business cycles is driven not only by the transmission of demand shocks, but also by supply-side links derived from production-sharing schemes induced by NAFTA. Bergin, Feenstra, and Hanson (2006) emphasize a key stylized fact: maquiladora “outsourcing” industries in Mexico experience fluctuations in value added that are roughly twice those of the corresponding industries in the U.S. Those authors develop two models of outsourcing to explain how domestic demand shocks in the U.S. are transmitted in such an amplified manner to Mexican outsourcing industries.

Interestingly, production of the services sector-accounting for about 65 percent of GDP in Mexico, and in principle not strongly dependent on external markets - is also highly correlated with U.S. economic activity. Figure 7 and the cross-correlogram in Table 14

\footnotetext{
${ }^{27}$ In theory, an increase in bilateral trade flows could lead to either higher or smaller business cycle synchronization between the trading partners. Most obviously, trade integration would strengthen the propagation of shocks in case demand shocks are dominant, especially through the effects on import demand. This effect could be either amplified or weakened depending on the production structure and specialization patterns induced by trade integration. On the one hand, if specialization leads to more inter-industry trade and shocks are mainly sector-specific, the net effect of increased trade on output comovement could become even negative. If, on the other hand, trade is mostly intra-industry, we should expect a higher synchronization of output, induced by the "back and forth” trade. See Frankel and Rose (1998), and Kose and Yi (2001).
} 
illustrate the high degree of comovement between output in the services sector in Mexico and U.S. GDP, industrial production, and total imports.

Figure 7. Synchronization Between Mexican GDP (Services) and U.S. Variables (1996Q1-2007Q4, yoy \% changes)
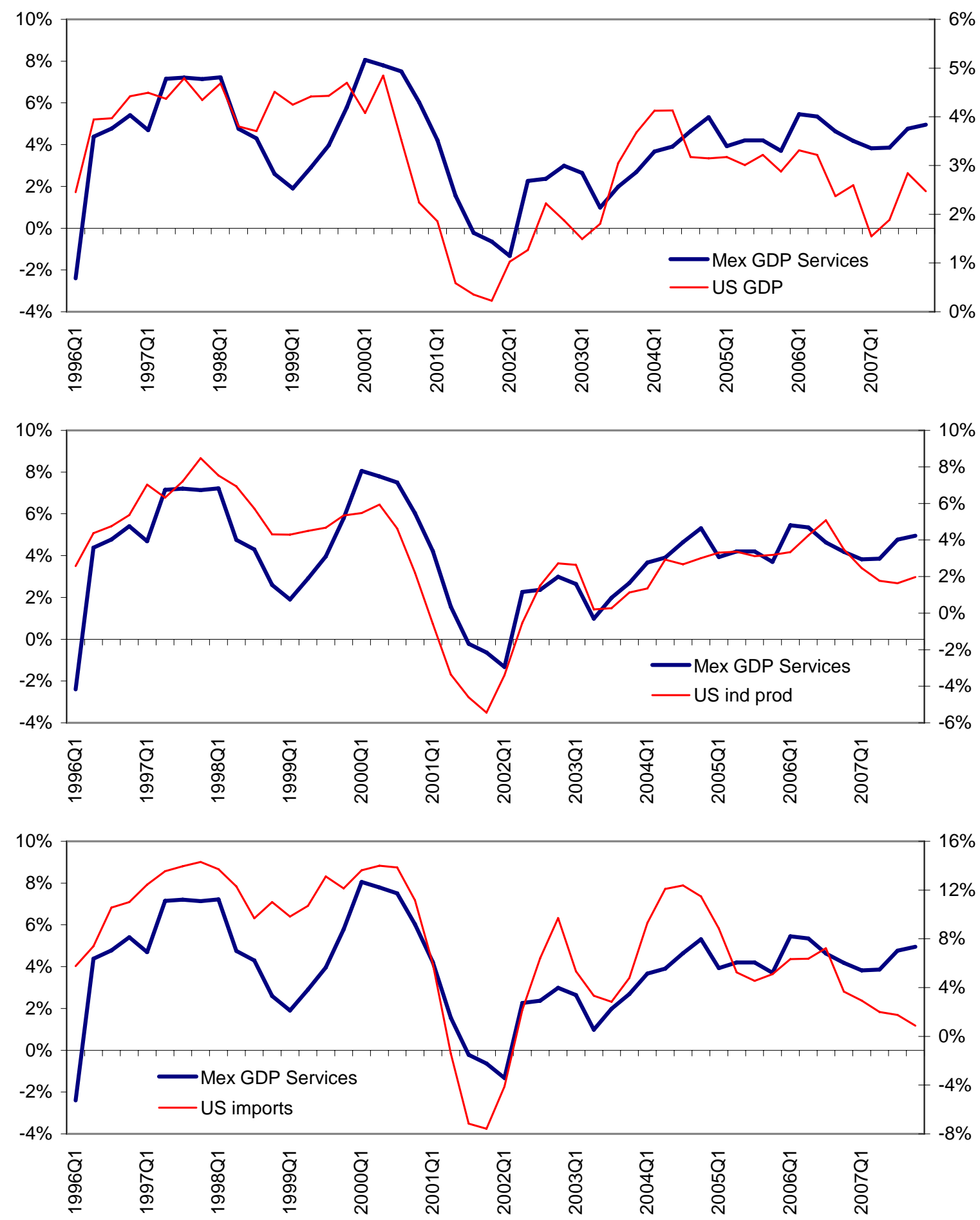
Table 14. Cross Correlations of Mexican GDP (Services) and U.S. Variables (yoy percent change, post-NAFTA period) $1 /$

\begin{tabular}{lcccccccccc}
\hline U.S variable & \multicolumn{7}{c}{ Cross correlations of Mexican real GDP (Services) in period $t$ and U.S. variable in period } \\
& $t-4$ & $t-3$ & $t-2$ & $t-1$ & $t$ & $t+1$ & $t+2$ & $t+3$ & $t+4$ \\
\hline Industrial production & 0.30 & 0.44 & 0.60 & 0.72 & $\mathbf{0 . 7 4}$ & 0.60 & 0.37 & 0.09 & -0.13 \\
Total imports & 0.17 & 0.33 & 0.53 & 0.68 & $\mathbf{0 . 7 2}$ & 0.59 & 0.30 & 0.01 & -0.18 \\
GDP & 0.43 & 0.57 & 0.69 & $\mathbf{0 . 6 9}$ & 0.64 & 0.41 & 0.19 & 0.02 & -0.07 \\
\hline
\end{tabular}

1/ Numbers in bold correspond to the peak quarter.

\section{A. Explaining Services Sector GDP, with Unrestricted VAR Models}

In order to shed light on the existence of potential spillovers from the export sector to the rest of the Mexican economy, an unrestricted VAR model is estimated, which includes U.S. industrial production, as well as Mexican exports and the services sector component of Mexican GDP. ${ }^{28}$ Variance decomposition analysis shows that 26 percent of output fluctuations in the services sector is explained by innovations in U.S. industrial production (Table 15). Taken together, U.S. industrial production and Mexican exports account for about 40 percent of the variation in services output.

Effects on the services sector seem to happen fairly quickly. Figure 8 shows the dynamic response of services output to a (one standard deviation) shock in U.S. industrial production. Growth in the services sector expands on impact, with a lasting effect of two years, with the peak occurring only one quarter after the shock. ${ }^{29}$ Given the small direct exposure-through trade channels — of the services sector to the U.S. economy, these results suggest the existence of important spillovers or amplifier effects stemming from the export sector to the rest of the economy in Mexico. ${ }^{30}$

This unrestricted VAR model is also estimated using U.S. GDP and U.S. imports instead of U.S. industrial production. Results show that 29 percent of output fluctuations in the services sector is explained by innovations to U.S. GDP (Table 16). Taken together, U.S. GDP and Mexican exports account for about 40 percent. The corresponding numbers in the

\footnotetext{
${ }^{28}$ The unrestricted VAR model is estimated including four lags, in first differences, and using quarterly data. Standard Choleski decomposition is used, and the ordering is as follows: U.S. industrial production, Mexican total exports, and Mexican GDP in the services sector.

${ }^{29}$ The unrestricted VAR is also estimated including government expenditures in the model. Once again, the main results from the variance decomposition and impulse response functions do not change dramatically.

${ }^{30}$ To provide some clues on which subcomponents of the services sector are driving the results, the correlation analysis as well as the unrestricted VAR were also conducted using each of the four subcategories of services GDP. The results suggest that the two categories most influenced by U.S. developments are "Trade, restaurants, and hotels," and "Transport, storage and communication." On the other hand, the category that appears to be least affected by U.S. growth shocks is "Finance, insurance, real estate, and business services." The category "Community, social, and personal services" constitutes an intermediate case.
} 
specification using U.S. imports are 31 and 45 percent respectively (Table 17). The dynamic response of services output to a (one standard deviation) shock in U.S. GDP and in U.S. imports is illustrated in Figures 9 and 10.

Table 15. Variance Decomposition of Mexico's Real Output in Services (in percent, post-NAFTA period)

\begin{tabular}{ccccc}
\hline Horizon & Standard Error & U.S. industrial production & Mexican exports & \multicolumn{2}{c}{ Mexican GDP services } \\
& & & $1 /$ \\
\hline 1 & 0.0069 & 5.28 & 4.57 & 90.15 \\
4 & 0.0086 & 25.72 & 14.86 & 59.41 \\
8 & 0.0087 & 26.43 & 14.84 & 58.73 \\
\hline
\end{tabular}

1/ This column indicates the proportion of fluctuations in real GDP (services) explained by its "own" shocks.

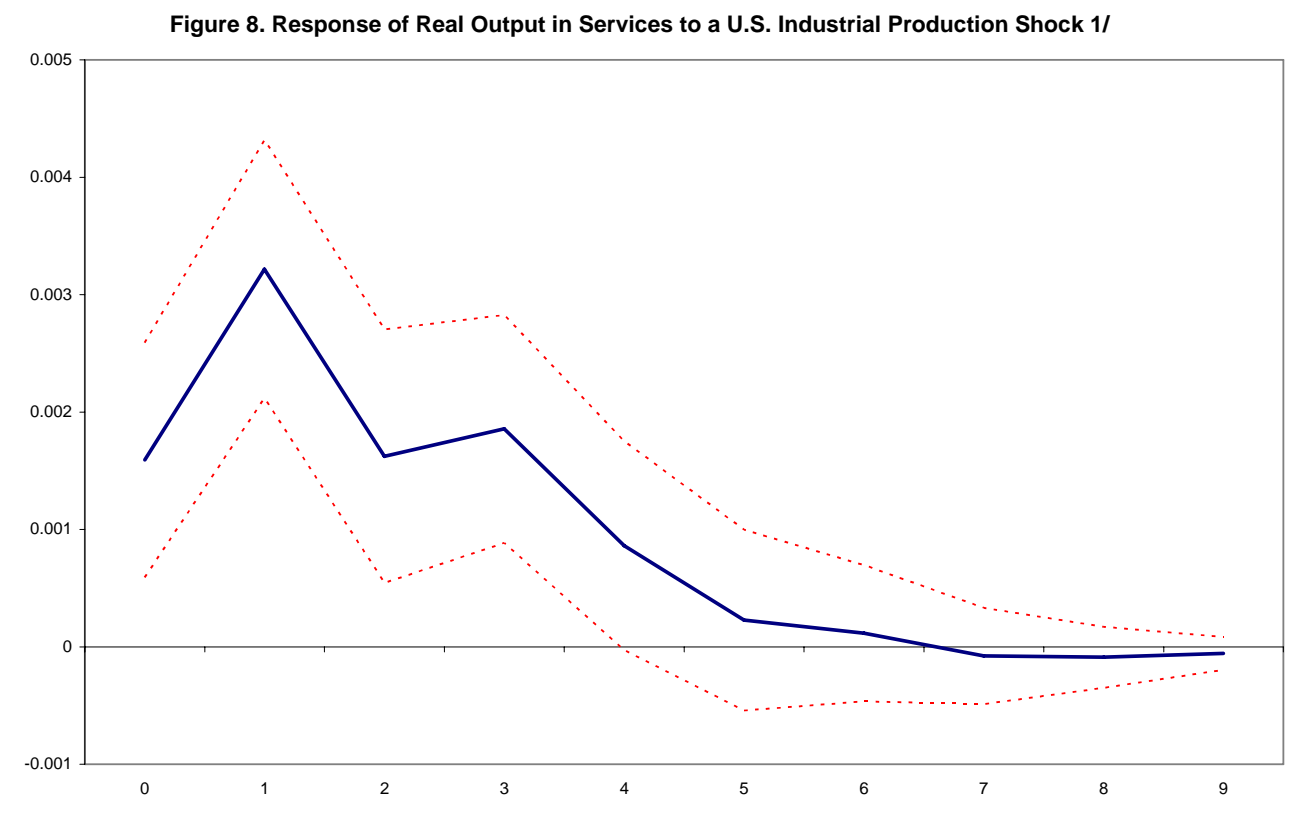

1/ Response to one standard deviation shock to U.S. industrial production growth rate ( 0.66 percentage points) + - 2 s.e.

Table 16. Variance Decomposition of Mexico's Real Output in Services (in percent, using U.S. GDP as a proxy for U.S. demand, post-NAFTA period)

\begin{tabular}{ccccc}
\hline Horizon & Standard Error & U.S. GDP & Mexican exports & $\begin{array}{c}\text { Mexican GDP } \\
\text { services 1/ }\end{array}$ \\
\hline 1 & 0.0044 & 3.16 & 5.24 & 91.60 \\
4 & 0.0052 & 26.50 & 10.99 & 62.51 \\
8 & 0.0053 & 28.75 & 10.71 & 60.54 \\
\hline
\end{tabular}

1/ This column indicates the proportion of fluctuations in real GDP (services) explained by its "own" shocks. 
Table 17. Variance Decomposition of Mexico's Real Output in Services

(in percent, using U.S. imports as a proxy for U.S. demand, post-NAFTA period)

\begin{tabular}{ccccc}
\hline Horizon & Standard Error & U.S. imports & Mexican exports & $\begin{array}{c}\text { Mexican GDP services } \\
1 /\end{array}$ \\
\hline 1 & 0.0159 & 27.27 & 1.82 & 70.91 \\
4 & 0.0196 & 31.50 & 13.23 & 55.27 \\
8 & 0.0197 & 31.31 & 13.86 & 54.83 \\
\hline
\end{tabular}

1/ This column indicates the proportion of fluctuations in real GDP (services) explained by its "own" shocks.
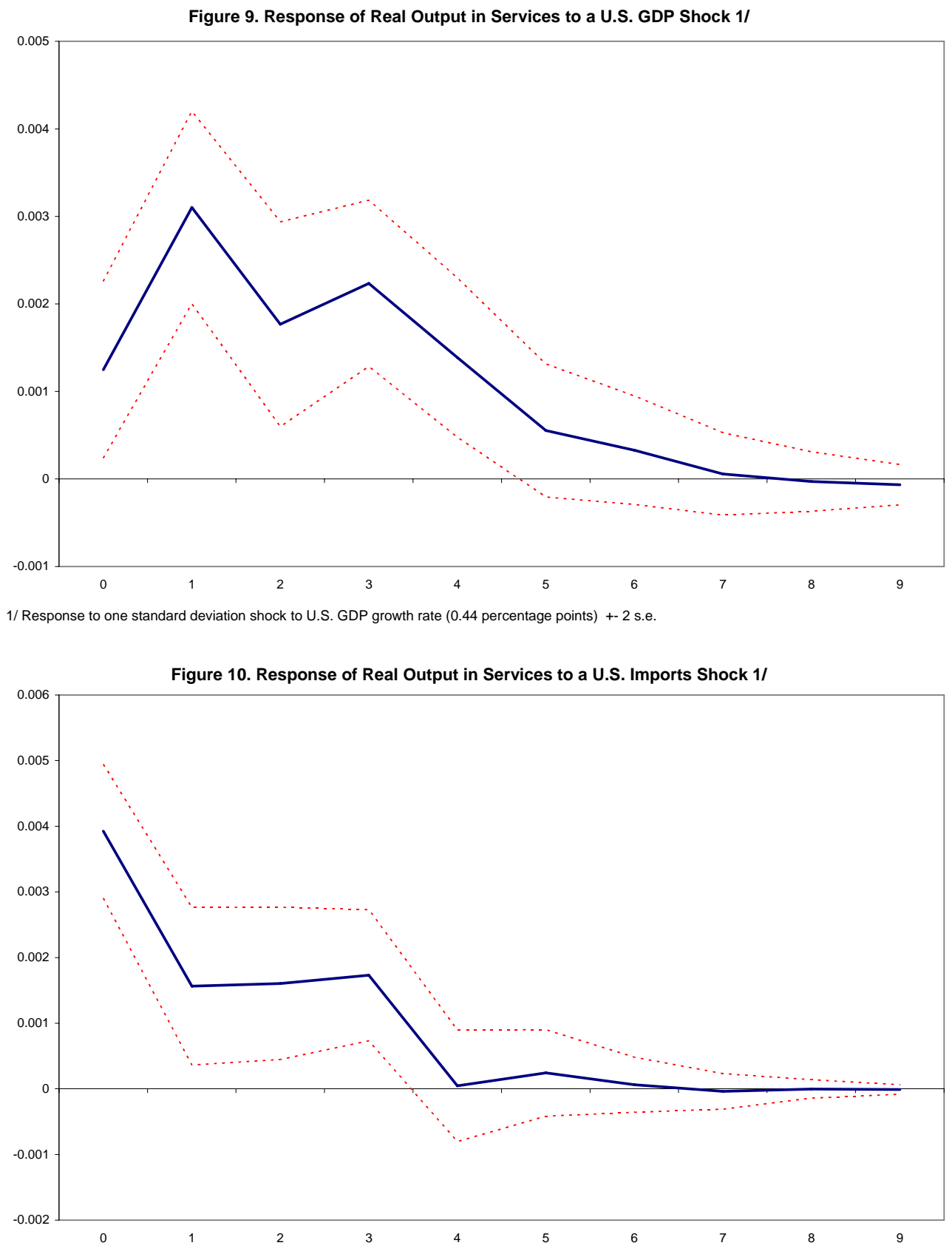

1/ Response to one standard deviation shock to U.S. imports growth rate (1.6 percentage points) +- 2 s.e. 


\section{B. Channels Other Than External Trade?}

Of course, shocks originated in the U.S. economy can be transmitted to Mexico through other channels, in addition to the trade channels on which our discussion has focused. Here, we note briefly three particular channels that might also be relevant (although empirical analysis of these potential channels is not part of this paper).

One potential channel through which the Mexican economy can be affected by U.S. economic conditions is the large flow of remittances from the U.S. to Mexico. It is thought that more than 10 million Mexican immigrants reside in the U.S., who sent about $\$ 23$ billion in 2007, an amount equivalent to 2.7 percent of GDP. The recent slowdown in remittances growth-remittances increased by only 1 percent in 2007, down from an annual rate of more than 15 percent in $2006^{31}$ —is likely due in part to the recent U.S. economic deceleration, particularly in sectors such as construction that employ a large number of immigrants. However, the Mexican economy is far less vulnerable to a slowdown in remittances flows than other economies in the region (particularly in some countries in Central America and the Caribbean where remittances-to-GDP ratios are above 15 percent). In fact, the magnitude of the slowdown for 2007—vis-à-vis a scenario where remittances had increased in 2007 at the same rate as in 2006-would equal US\$3.3 billion, about 0.35 percent of GDP. If this amount were to translate entirely into reduced domestic demand (i.e., making an extreme assumption that all remittances are spent fairly soon after they are received), the short-run effect on GDP would not be dramatic, though it could be non-negligible.

Another potential propagation mechanism is the large flows of foreign direct investment (FDI) coming into Mexico from its big neighbor. In fact, FDI flows from the U.S. accounted for about 60 percent of FDI in Mexico since the inception of NAFTA. As noted by Calvo, Fernandez Arias, Reinhart, and Talvi (2001), FDI flows from the U.S. to Latin America have been highly procyclical, contracting during downturns in the U.S. economy and increasing during expansions, leading to higher synchronization of business cycles in the region.

Finally, an additional potential link between the U.S. and Mexican economies is given by the large presence of U.S. and other international banks in the Mexican banking system. Foreign banks represent about 80 percent of the Mexican banking system, in principle creating a channel through which changes in financial conditions in the U.S. or other mature markets could influence financial and real developments in Mexico.

\section{CONCLUDing REMARKS}

The recent slowdown of the U.S. economy has strengthened interest in a key question: how do changes in U.S. economic conditions tend to affect the business cycle in Mexico? The main results of this paper confirm that shocks to U.S. real variables—such as U.S. industrial

\footnotetext{
${ }^{31}$ According to data from Bank of Mexico.
} 
production-explain a large share of fluctuations in Mexico’s output and exports, constituting the largest foreign source of macroeconomic fluctuations in Mexico. The relative importance of U.S. influences has been higher in the post-NAFTA period, partly reflecting greater trade integration-but also Mexico’s own “Great Moderation,” as the country escaped its former pattern of macro-financial crises. In the last decade, Mexico’s output fluctuations have been of the "normal business cycle" variety, and moreover closely synchronized with those of the U.S. In fact, the overall impact of a U.S. growth shock on Mexican growth seems to be large, almost one-for-one, as a rough rule of thumb.

Interestingly, the most important U.S. variables for Mexico relate to U.S. output-U.S. industrial production or simply U.S. GDP — rather than to U.S. domestic demand. This finding likely reflects the extent to which Mexico’s exports are inputs to U.S. production, rather than satisfying final domestic demand-a trade pattern that would work to Mexico's advantage if the large U.S. current account deficit were to contract abruptly (i.e., with U.S. domestic demand being affected much more than U.S. output).

The key role played by U.S. factors in driving Mexican output fluctuations is especially interesting given the still relatively low share of exports, and value added from exports, in Mexico’s GDP. Section V has shown that even services-a sector not so directly dependent on foreign markets - seem to be influenced by developments in the U.S. economy, suggesting the existence of important spillovers or amplifier effects from the export sector to the rest of the economy in Mexico. A deeper understanding of these spillover effects, as well as a quantitative assessment of other potential channels of transmission of shocks stemming from the U.S. - some of which were discussed in this paper-are important areas for future research. 


\section{REFERENCES}

Buckle, Robert A., Kunhong Kim, Heather Kirkham, Nathan McLellan, and Jared Sharma, 2002, “A Structural VAR Model of the New Zealand Business Cycle,” New Zealand Treasury Working Paper 02/26, December 2002.

Bergin, Paul, Robert Feenstra, and Gordon Hanson, 2006, “Outsourcing and Volatility.”

Calvo, Guillermo, and Leonardo Leiderman, and Carmen Reinhart, 1993, "Capital Inflows and the Real Exchange Rate in Latin America: the Role of External Factors," Staff Papers, International Monetary Fund, Vol. 40, pp. 108-50.

Calvo, Guillermo, Eduardo Fernandez Arias, Carmen Reinhart, and Ernesto Talvi, 2001, "The Growth-Interest-Rate Cycle in the United States and its Consequences for Emerging Markets,” Inter-American Development Bank Working Paper No. 458.

Calvo, Guillermo, Eduardo Fernandez Arias, Carmen Reinhart, and Ernesto Talvi, 2001, "Growth and External Financing in Latin America," prepared for the Annual Meetings of the Board of Governors, Inter-American Development Bank and Inter-American Investment Corporation.

Chiquiar, Daniel, and Manuel Ramos-Francia, 2004, “Bilateral Trade and Business Cycle Synchronization: Evidence from Mexico and United States Manufacturing Industries,” Banco de Mexico Working Paper No. 2004-05.

Cuevas, Alfredo, Miguel Messmacher, and Alejandro Werner, 2003, "Macroeconomic Synchronization between Mexico and its NAFTA Partners,” Banco de Mexico Working Paper No. 2003-01.

Cushman, David, and Tao Zha, 1997, "Identifying Monetary Policy in a Small Open Economy Under Flexible Exchange Rates,” Journal of Monetary Economics, Vol. 39, pp. 433-48.

Dungey, Mardi, and Adrian Pagan, 2000, “A Structural VAR Model of the Australian Economy,” The Economic Record 76, pp. 321-42.

Frankel, Jeffrey A. and Andrew K. Rose, 1998, “The Endogeneity of the Optimun Currency Area Criteria,” The Economic Journal, 108 (449), 1009-25.

Franken, Helmut, Guillermo Le Fort, and Eric Parrado, 2005, "Business Cycle Responses and Resilience of the Chilean Economy During the Last Fifty Years," Central Bank of Chile Working Paper No. 331.

Herrera, Jorge, 2004, "Business Cycles in Mexico and the United States: Do They Share Common Movements?,” Journal of Applied Economics, Vol. VII, No. 2, 303-23. 
Hoffmaister, Alexander W., and Jorge E. Roldos, 2001, “The Sources of Macroeconomic Fluctuations in Developing Countries: Brazil and Korea,” Journal of Macroeconomics, Winter 2001, Vol.23, No. 1, pp. 213-39.

International Monetary Fund, 2007, Regional Economic Outlook: Western Hemisphere, April 2007.

Izquierdo, Alejandro, Randall Romero, and Ernesto Talvi, 2007, "Business Cycles in Latin America: The Role of External Factors.”

Jean Louis, Rosmy, and Daniel Simons, 2005, “Does a North American Business Cycle Exist?”

Kaminsky, Graciela, Carmen Reinhart, and Carlos Végh, 2004, “When it Rains, it Pours: Procyclical Capital Flows and Macroeconomic Policies,” NBER Macro Annual.

Kose, M. Ayhan and Kei-Mu Yi, 2001, "International Trade and Business Cycles: is Vertical Specialization the Missing link?,” American Economic Review, 91 (2), 371-75.

Kose, M. Ayhan, Guy Meredith, and Christopher Towe, 2004, "How Has NAFTA Affected the Mexican Economy? Review and Evidence,” IMF Working Paper 04/59 (Washington: International Monetary Fund).

Oliveira Santos, Andre, 2002, “Are Mexican Business Cycles Asymmetrical?,” IMF Working Paper 02/150 (Washington: International Monetary Fund).

Osterholm, Par, and Jeromin Zettelmeyer, 2007, “The Effect of External Conditions on Growth in Latin America,” IMF Working Paper 07/176 (Washington: International Monetary Fund).

Raddatz, Claudio, 2006, “Are External Shocks Responsible for the Instability of Output in Low-Income Countries?,” Journal of Development Economics, November 2006.

Sims, Christopher, 1980, “Macroeconomics and Reality,” Econometrica, 48(1), pp.1-48.

Sosa, Sebastian, and Paul Cashin, 2008, "External Shocks and Macroeconomic Fluctuations in the Eastern Caribbean,” IMF Working Paper (forthcoming; Washington: International Monetary Fund).

Stock, James H., and Mark W. Watson, 2001, “Vector Autoregressions,” Journal of Economic Perspectives, Vol. 15, No. 4, pp. 101-15.

Swiston, Andrew, and Tamin Bayoumi, 2008, “Spillovers Across NAFTA,” IMF Working Paper 08/3 (Washington: International Monetary Fund).

Torres, Alberto and Oscar Vela, 2003, “Trade Integration and Synchronization Between the Business Cycles of Mexico and the United States," North American Journal of Economics and Finance, 14 (2003), pp. 319-42. 